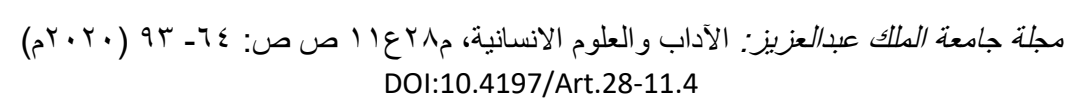

\title{
خطاب شجن الذات ما بين الآمال والآلام- قراءة نصية لنماذج من شعر امرى القيْس
}

\section{د. محمود سليم محمد هياجنه \\ أستاذ الأدب والنقد المشارك مكود}

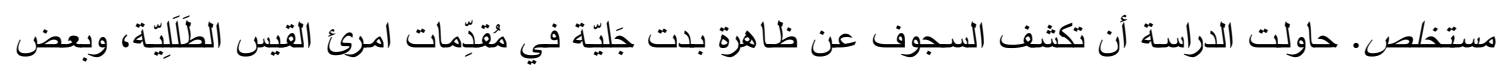

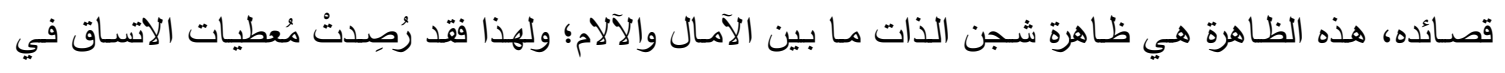

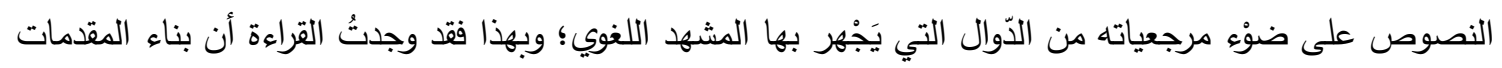

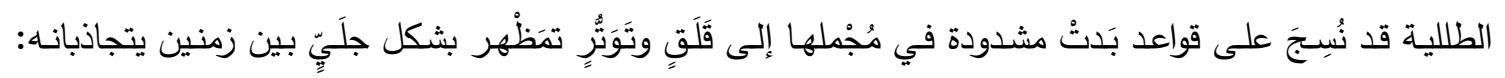

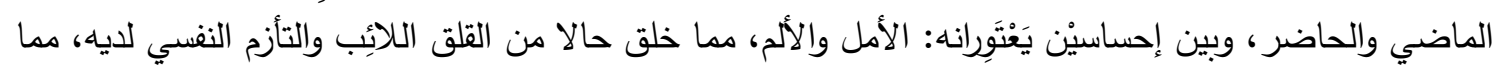

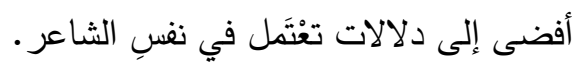

إزاء ذلك؛ وققتُ الدراسة عند هاتيك الظاهرة، محاولة تجليتها، قصْد الوقوف على مضامينها ومرجعياتها النفسية المؤسسة لمثل هذه الظاهرة، التي غَدَتْ نسقا خاصا في كثير من مقدماته الطللية وبعض قصائده. الكلمات المفتاحية: امرؤ القيس، شجن الذات، الآمال والآلام، خطاب.

قد حظي بقراءات مُتعـدة كثيرة، ولعـلّ ذلك يعـود لتعدد المناهج والاتجاهـات والرؤى التي كان يمتاح منهـا هـؤلاء، فضـالا عـن أن تعـدد القـراءات يكثـف بجـاءع عـن ثـراء الـص وغنـاه بالأسـرار والـدلالات والإيحاءات التي تتناءى عن التقريرية والمباشرة.

\section{المقدمة}

تحـاول هذه الدراسـة أنْ تكتنـه عـالَم النص الثـعري لشعر امرىء القيس- عبر ثُلّة من المقدمات الطللية فـي قصــائده، وبعـض قصــائده- لتجليــة عالمـــه الشعري، وهي إذ تفعل ذلك، لا تتسى أنّ جُلَّ شعره 
حدود الدراسـة: وأما الحدود المكانية فقد كانت في

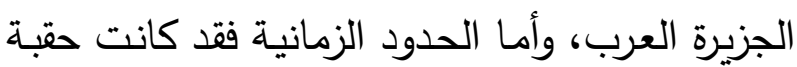

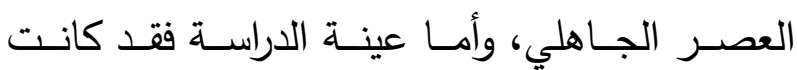
المقدمات الطللية للشاعر امرئ القيس. أدبيات الاراسة: وقد تتاول باحثون وأدباء ومفكرون كثر شعر امرئ القيس، فضلا عن تتاولهم للمقدمات الطللية -بشكل

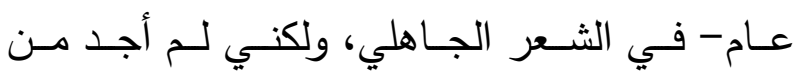
خصص دراسته في المقدمات في شعر امرئ القيس، ومن هذه الدراسات: دراسة كمال أبو ديب في كتابه

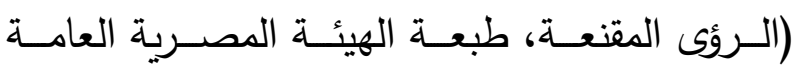

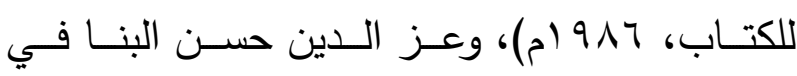
كتابـه(الكلمات والأشـياء، التحليـل البنيـوي لقصـيدة

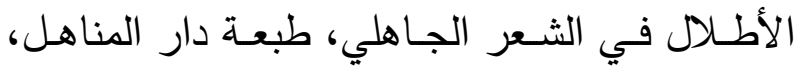

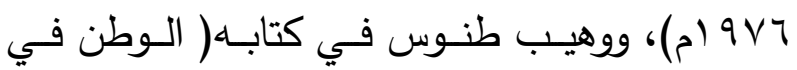
الثـعر العربي من الجاهلية إلى نهاية القرن الثاني

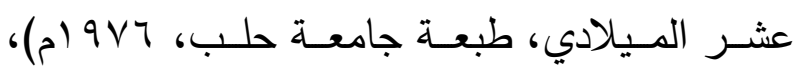
ودراسـة حسين عطوان( مقدمـة القصيدة في الثـعر

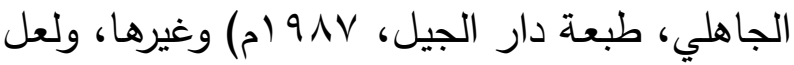

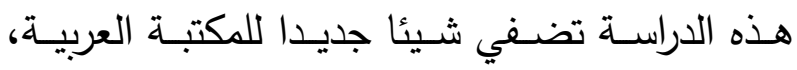
ولطلاب العلم. - ملمده المقدمة الطلية في معلقة امرئ القيس المشهورة: وأول ما تستهل به هذه المقاربة، هو المقدمة الطللية

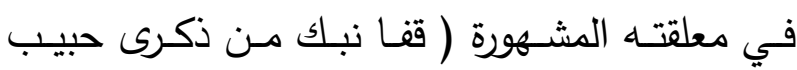
ومنزلِ).
ولذا ستتهض هذه الورشة بمحاولة جادة اكتناه عالم النص، متجاوزة البنى السطحية إلى ما وراء السجوف

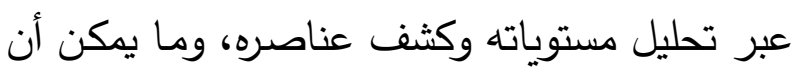
يضيفه فعل القراءة النقدية إلى الملفوظ النصي، ولذا

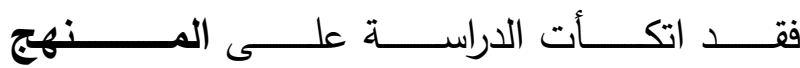
التأويلي (الهرمنيوطيقا) الهادف إلى كثف المعاني الخفيـة المتواريــة خلف العبـارات الظـاهرة، ومتوسـلة بالمنهج الوصفي التحليلي.

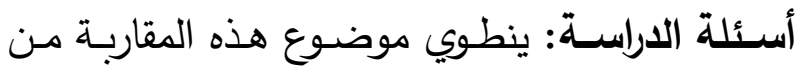
خـلال مسـاءلة تسَبْرُ في معـايير الفهم ومسـتوياته،

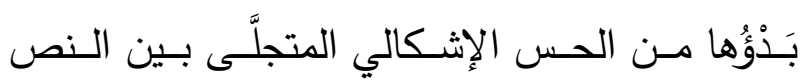

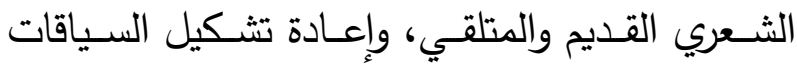
التاريخية والثتافية والاجتماعية للنص الثعري القديم، وقراءتها قراءة جديدة مستفيدين من المناهج الحديثة . مشكلة الدراسة: وتتجلى مشكلة الدراسة فيما تضمنه موضـوع الدراســة البـارز في عنوانهـا، وعلىى هـذا الأسـاس تسلط الدراسـة الضـوء على الجوانب الفنيـة والجمالية التي تجعل من النصوص المدروسة تميزا أكسبها الخلـود، كمـا تتجلى في نفـي ذاتيـة الثـعر الجـاهلي المطلقــة؛ فالدراسـة تحـاول اثبـات امتـزاج الذات بالموضوع، ومعادلة التعبير والإحساس، فضلا لألان عن أن اللغة والصورة والإيقاع عناصر تؤكد غنائية التعبير لا غنائية الذات، فكما أن الذاتي في الثـعر عند يؤشر على الموضوعي، فإن الموضوعي يدل على

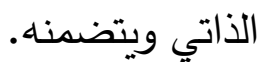


للنفاذ إلى ما يكتنهها من تجليات وإيحاءات، سواء أصابوا أم غير ذلك.

والمقاربـة إذ تبيح لسفينتها الولوج في عـالم المقدمـة الطلية لقصيدة امرىء القيس، تزعم أن منهجها في البحث يختلف نوعا ما عن المناهج التي تتاولتها، حيـث تنظر في أعطـاف النص مـن خـلال رؤيسة

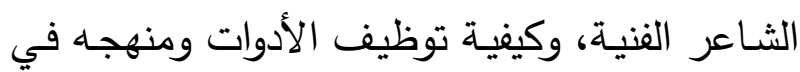

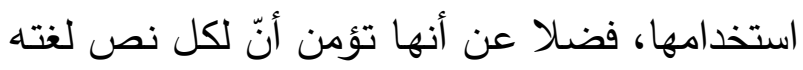
المتزامنة مع المعنى الظاهري باعتبارها فعلا إبداعيا يتوسل بـه الداخل للانكثـاف، ولكل نص - أيضـا-

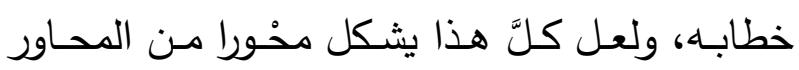
الأساسية في القراءة. نص المقدمة الطلاية:

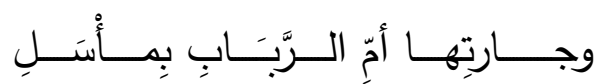

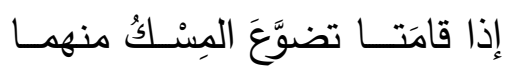

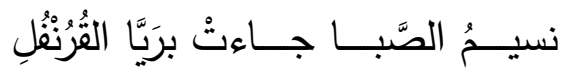
ففاضَتُ دموعُ العَيْنِ مِنّي صَبابةً على النحر حتى بلَّ دمعي محمَلِي" (1) .

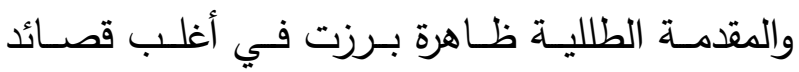
الثـعر الجــاهلي، وهـي أن الثــعراء فـي العصــر

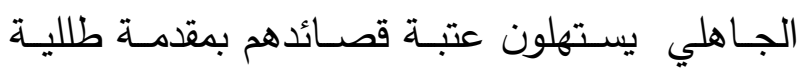

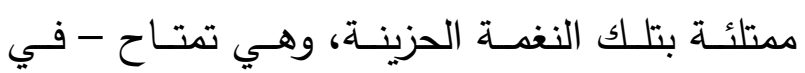
الأغلب- من أصداح انقلاب الحال وتغير الأحوال، وهن

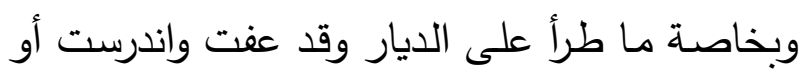

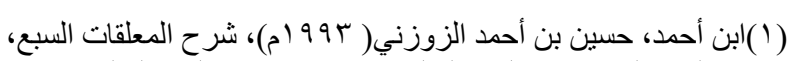

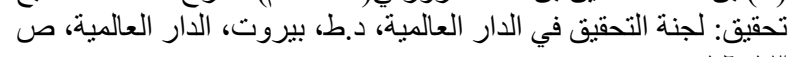

ومما لا شك فيه أن يراع أعلام الفكر والأدب والنقد

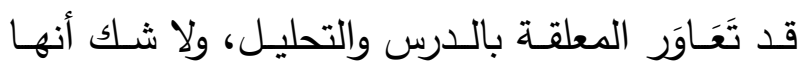
تفاوتت قِصَرا وطولا، ومنهجا وشِرعة، ولا يعني هذا

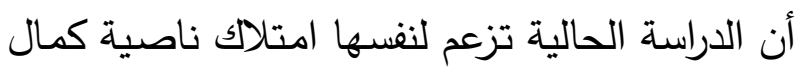
المقاربـة النصية، ولا تزعم كذلك الوصسول إلى سدرة التلاقي مـع المعطيات التي يبوح بها النص ويمتاح

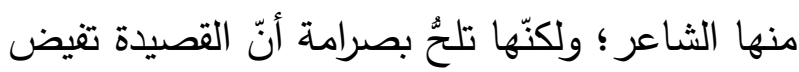

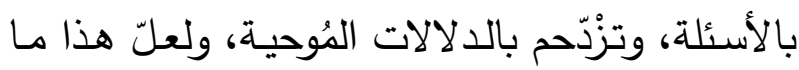

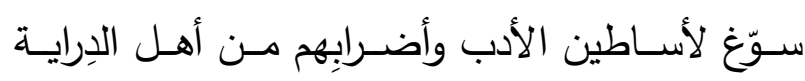

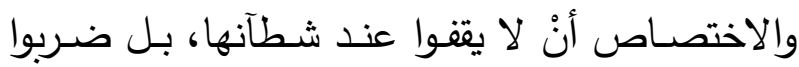

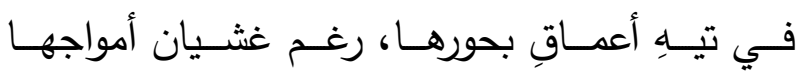
المتلاطمة بُحب متكاثفة، ولهذا فقد حاولوا أنْ ينزلوا

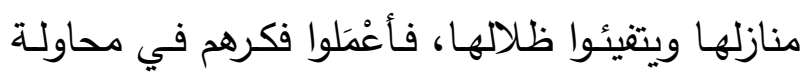
" قفا نْبْكِ مِنْ ذِكْرى حبيبٍ ومَنْزِلِ

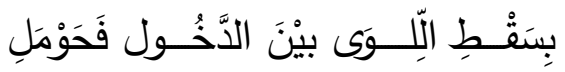

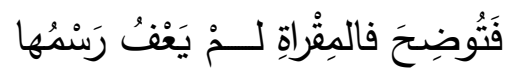

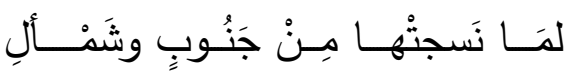

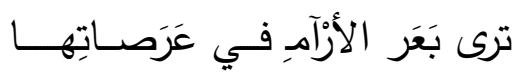

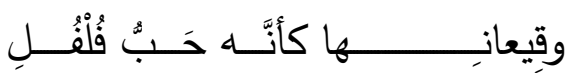

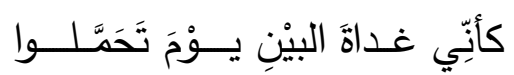

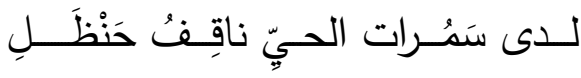

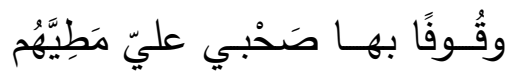

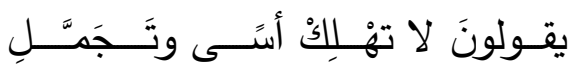

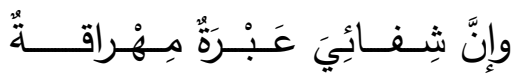

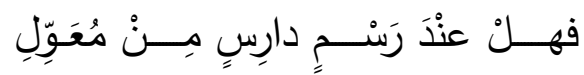

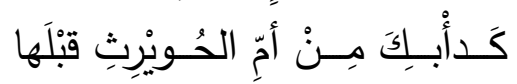


" والوقوف على الأطلال عامة، وذكر الدنازل الديار

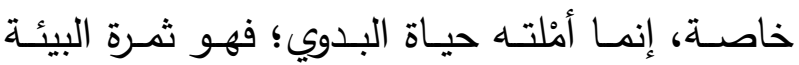
المتنقلـة التي كـان يَحْياهـا العرب البـادون، أو ثمـرة منازل القبيلة الأصيلة في القرى أو أثباه القرى، التي لئياهي

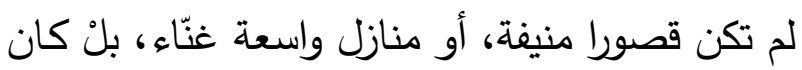

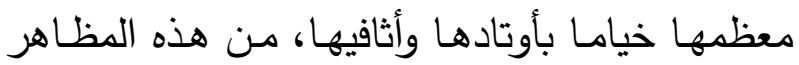

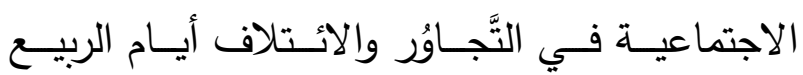
والصيف، والابتعاد والاقتران أيام الفصول الأخرى، الأني كانت هذه الظاهرة في الوقوف على الأطلال، والبكاء عليها والحنين إليها واستثارة الذكريات والتهويم في التهون مجالات التعبير الشعوري، وهي ظاهرة اتخذت حيّزا

من الشعر الجاهلي خاصة من شعر الغزل"(").

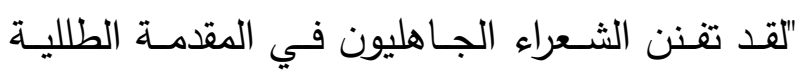

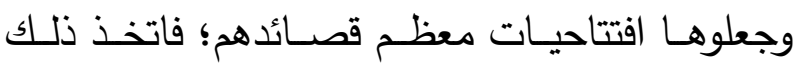
أشكالا وأساليب وصور متعددة، وكاد كثرة الثعر في

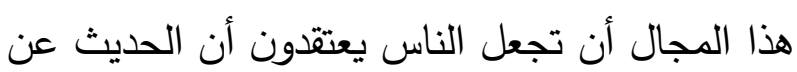

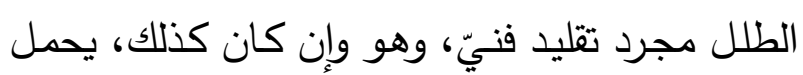

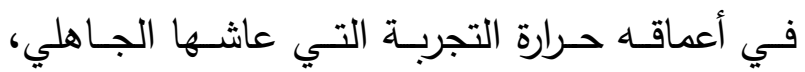
وتجربة الغربة عن الذات جزء منها، وقد يوفق شاعر في التدقيق أو التعبير الفني أكثر من آخر ، ولكنة ولكن يوفن المهم هو حرارة التجربة"(؛).

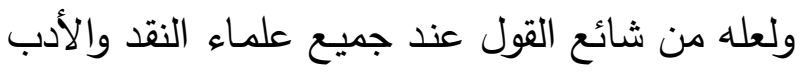

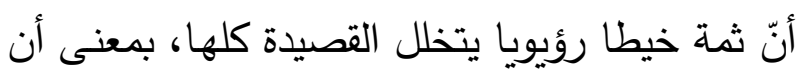

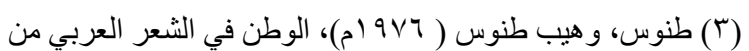

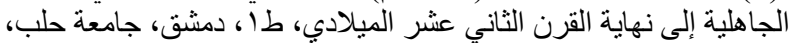

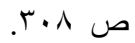

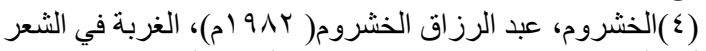

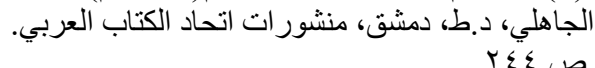

كادت آثارهـا أن تمحى، ولـذلك يلجـأ الثـاعر إلىى المقايسـة بين مـاض مضسى وحاضـر معيش، سواء

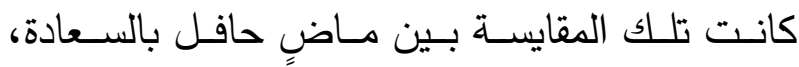
وحاضر مضطرب قلق متوتر أو غير ذلك.

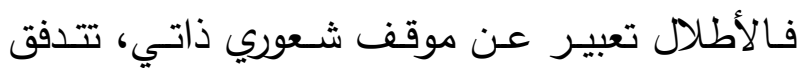
على إثره دفقـات شـورية ذاتيـة مـن مشـاهدة تلك لك المحال المندرسة البالية؛ لتصبح الذات متناوسة بين قطبين: ( الماضي والحاضر ) يتجاذبانها، وإن كان هذا لا يندرج على كل الأطلال؛ فقد يكون الماضي

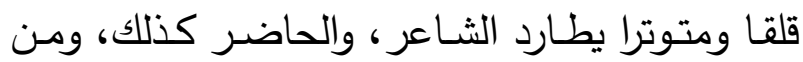

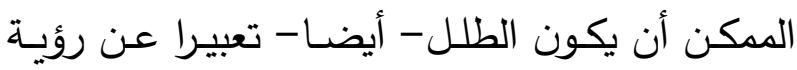
عميقة تعبر عن معنى الديمومـة والخلود أو تعبيـرا

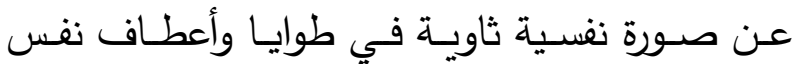
الثاعر ؛ فالإنسان بطبيعته مجبول على حب الخلود

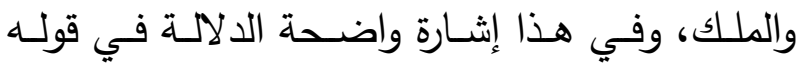

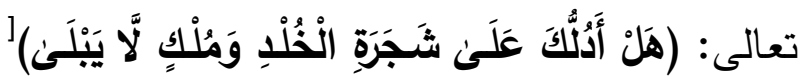

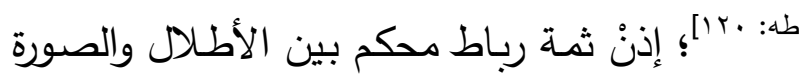

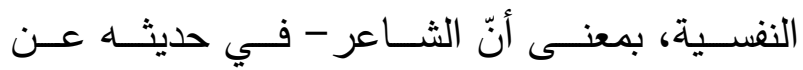
الأطلال - يكرس ثنائيتين: " الزمن في مروره يُجرِّد الأشياء ويعزّيها، لكنها في الوقت نفسه يُخلّد الأشياء ويمنحها الديمومة"(؟). ولعـل مقاربـة المقدمـة الطلليـة مـن خـلال السـياق والإطسار التلذيْن أنتجاهـا، يكون عتبـة لتسليط الضونْ على النص ضمن رؤيـة الثـاعر وفلسفته، والتسليم لخهي بخصوصيته أسلوبا وتركيبا ورؤية.... إلخ.

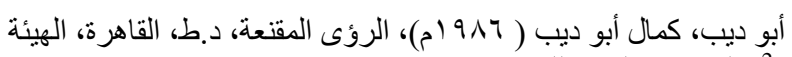

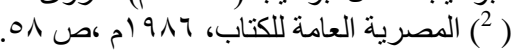




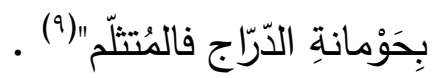
وهو هنا أخرج الكلام في مقام الثك في هذه الدار أهي لها أم لا؟ ليُخبرنا على بُعْد العَهد والأمد.

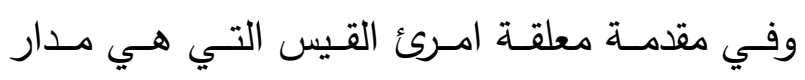

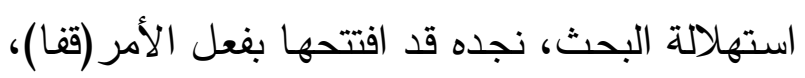

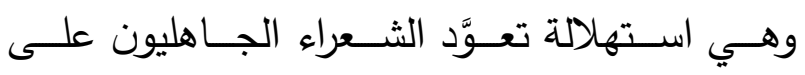

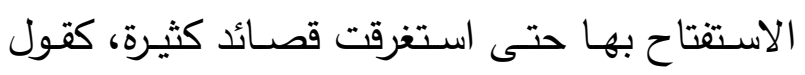
زهير بن أبي سلمى:

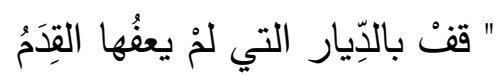

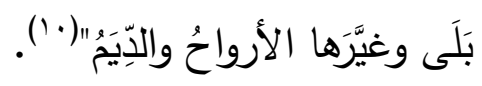

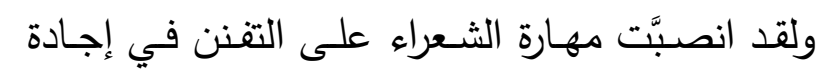

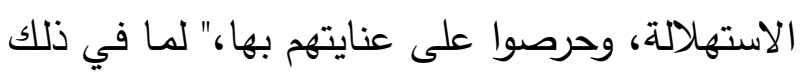

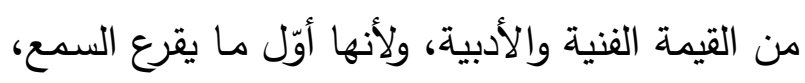
وبها يُستدل على ما عند الثاعر من أول وهلة"(').

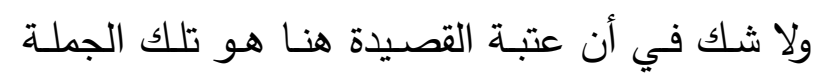

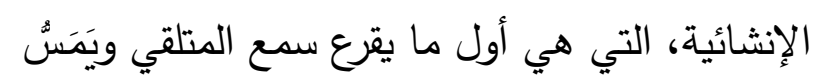

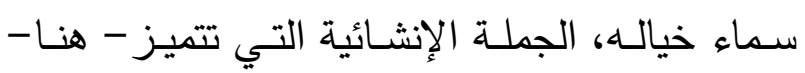
بـالأمر والطلـب، مـن الأنـا الثـاعر إلـى الثنائيـة

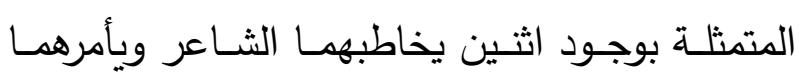
بالوقوف، وسواء كان الاثنان على الحقيقة أم كانـا

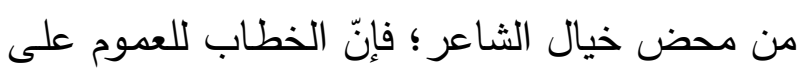

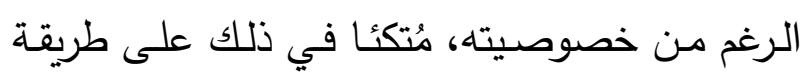

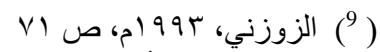

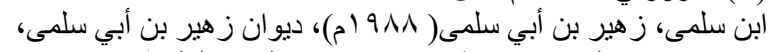

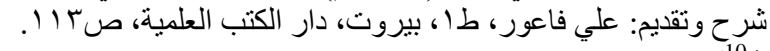
(1 (1) القيرواني، ابن رشيق القيرواني، الحسن بن علي( (19 (م)، العمدة

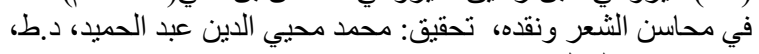

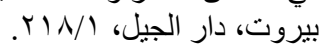

المقدمـة الطللية لم تكن تنأى عن القصيدة؛ ولكنها

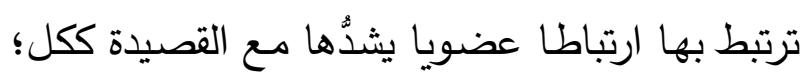
فهي بناءٌ متكاملُ متتاسق. وعند الرجوع للمقدمات الطلية تجد أنها إما أن تبدأ

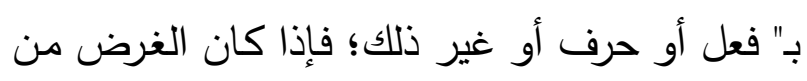
الإخبارِ الإشعار بزمان ذلك الثبوت؛ فالمستعمل في دان

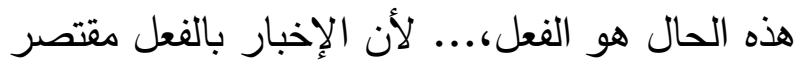
على الزمانيات أو ما يُقدّر فيه ذلك" (0).

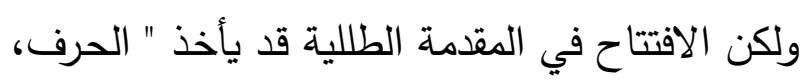

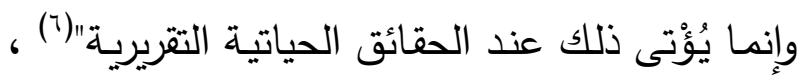
وعنصر من عناصر التوكيد والاهتمام، وأما الافتتاح بالفعل؛ فكقول لبيد بن ربيعة العامري:

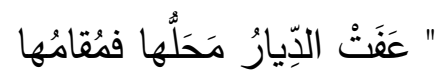

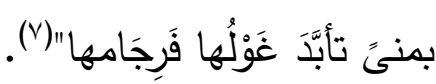
وأما الابتداء بالحرف كقول طرفة بن العبد:

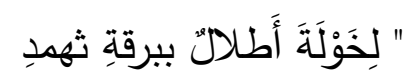
تلوحُ كباقي الوشمِ في ظاهرِ اليدِ"(^).

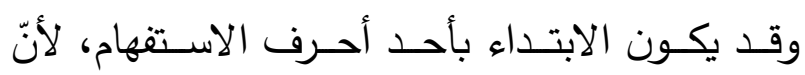
الاستفهام مشـعرٌ بامتلاء نفس الثـاعر بـه؛ إذ يفيد

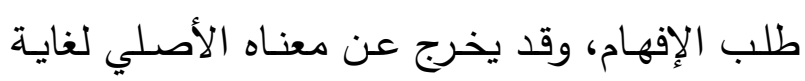

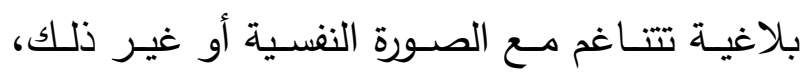

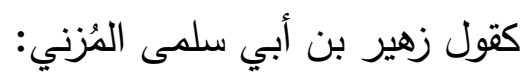

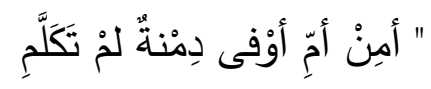

خريوش، حسين خريوش ( 999 (م)، بنية التراث الروحي الاجتماعي الإني

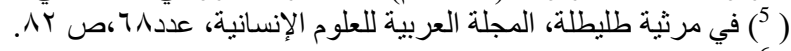

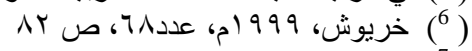

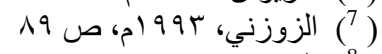

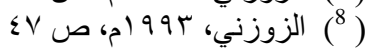


أن الشـاعر يعـيش غربــة مكانيــة ويعـيش ســاعة الاحتضار في أرض الغربة.

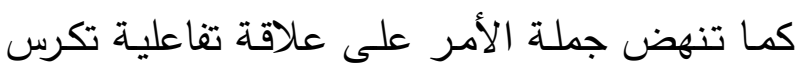
حالا من الاتساق بين موقفين اثثين، همـا: الوقوف والبكاء، والعلاقة بينهما تتعمق شعوريا على أسـاس مـا تحيل عليـه فاعليـة كل منهمـا؛ فـالوقوف يسـوغه الاسـتعطاف ومشـاركة المتألم المتوجـع، وعدم تركـه يقاسـي الألم وحده؛ إذْ المشـاركة في المواقف الجَلَل تخفف المصساب، ولعلها تحِدُّ من حِدَّتهُ، أضف إلى إِى ذلـك أن بــثَّ الحـزن لمـن أراد مـنهم الوقـوف، فيـهـ تخفيف كذلك. أما البكاء فيسوغه ارتهان قلب الشاعر من المحبوبـة التي أرَقَتَهُ وأثثارت أثجانه، وهكذا يتحقق للشـاعر من وراء هذا الخطـاب وهـذا الترتيـب سـرٌّ عميق يقرِّب المعنـى المـراد، والدلالــة البعيدة، في تصـعيد البُعْد العـاطفي بطريقـة تكثـف عـن الثـعور الحـاد للـذات الشاعرة. لنتأمل الآن الجملة التي صـاغها الثـاعر من حيث مضدونها، التي تتمحور حول أسباب البكاء:( من ذكرى حبيبٍٍ ومنزل). لا شـك في أن الجملـة باسـتغراقها تكرِّس علامتين: زمانيـة ومكانيـة؛ فقوله: ( مـن ذكرى) تكرس الزمن الماضي، وقوله:( ومنزل) تكرس المكان الذي كانت تقطنهـ الحبيبـة، بمعنسى أننـا أمسام بُعْديْن: بُعدّد زمني وبعد مكاني، وكلاهما يدور حول ( الوقوف والبكاء)، والعلاقـة بينهـا تتعمق ضـيا على أسـاس مـا تحيل
العـرب وعـادتهم، كمـا أنّ لهمـا دلالتهمـا العميقـة في نفس الشـاعر سواء أدركنا ذلك أم لم ندرك، هذا من جهة، وإن الابتداء بفعل الأمر لله ما يبرره من جهة

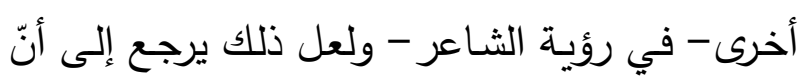
أمرًا جلال يستدعي ذلك، ولولا ذلك لما فعل ذلك. إن هذا الأسـلوب- الاسـتهلال بفعـل الأمـر - يعتمـد

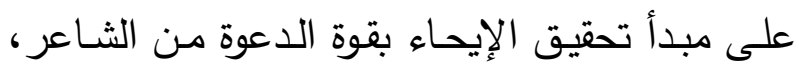
كي يبث ما في وجدانه من مشاعر وأحاسيس، وما يعـلج فيها مـن نغمـة عاطفيـة تنكشف في الكلمـة الثانية بعد فعل الأمر وفي ثنايا القصيدة. ولعل سر الجمـال في الأمـر المجازي هو أنـه ينقل المتلقي من مضدون الكلام اللغوي إلى ما وراءه من لطائف بلاغية، أو يوقفه على الغرض الذي يهدف إليـه الشـاعر ويترجم أحاسيسـه ومشـاعره، وهو هنـابزعم الباحث - أمر خرج عن معنساه الحقيقي الذي

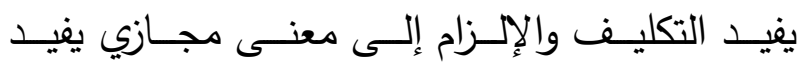
الاسـتعطاف والالتمـاس المتضــمن مشــاعر الوجـع والأسى، وهذا يمكن فهمه من خلال الصورة النفسية للثـاعر ومـن قرائن الأحـوال وسـياق الكـلام. يقـول مالك بن الريب: - مابك فيا صاحبَيْ رخْلي دنا الموتُ فانزلا برابية إني مقيم لياليا"(r'). فقوله: انزلا، فعل أمر خرج عن المعنى الحقيقي إلى معنى مجـازي يفيد الاستعطاف، وبخاصـة إذا فهمنـا

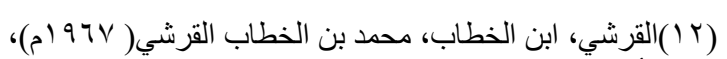

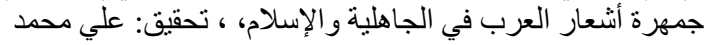

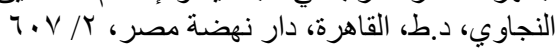


الثـاعر في هذا البيت "يضـاعف من حيويـة الرسم

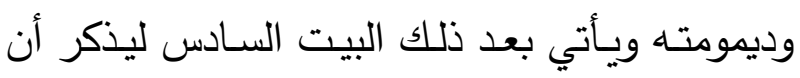

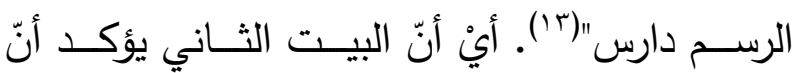
المكان لمْ يُدْرس ولْم يتغير ولم يُمْحَح أثره، على الرغم

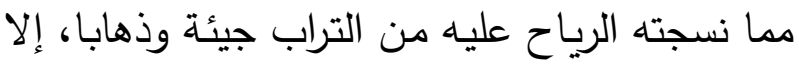

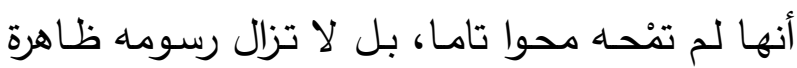

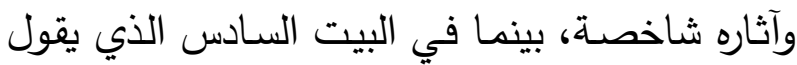

وإنَّ شِفائي عبرةٌ مُهْراقةٌ

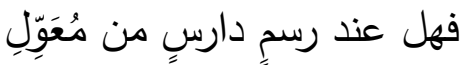

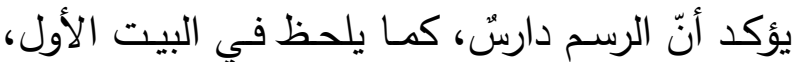

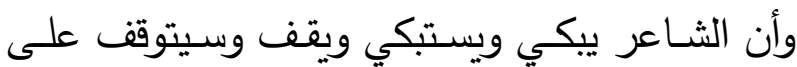
رسم لم يزل ولم يتغير، ونلحظ- أيضا- في البيت وليت ولئي

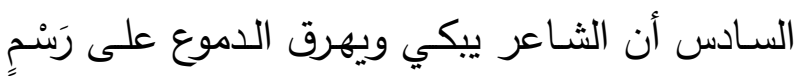

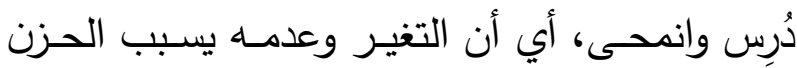
والألم والبكاء. هنا نعمل على تفسير سيطرة الحزن والحنين والبكاء، لأن أساس المعادلة انبنى على البكاء في كل حال،

$$
\text { سواء اندرس المكان أم ثبت. }
$$

ترتبط هذه المقدمة ( الطلية) ارتباطا واضحا بثنائية الماضـي والحاضـر ، كمـا أنها ترتبط ارتباطـا مكينـا

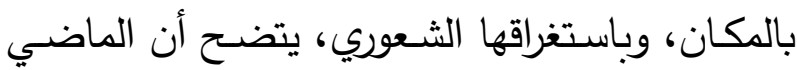
لا يَخْقُق توازنا مع الحاضر ، بل نجد الحاضر يَخْلق حالا من التوتر اللائب، كما أن الماضي يثير الحزن لهن

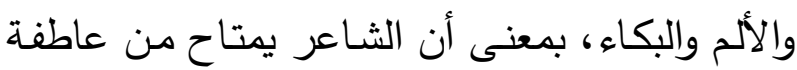

إليـه فاعليـة كل منهمـا- بالنسبة للشـاعر - فـالزمن، زمنان: زمن ذهب وانصرم وزمن حالي إلا أنه حامل للذكريات التي تنطوي في أعطاف الزمن الماضي، والمكان: مكانسان وإنْ كانسا واحدا: مكان ماثل في ذاكرة الثـاعر، ومكان مندرس حامل للذكرى التي غمرها الزمان الماضي وطواها، ولٌْ يبقَ من المكان

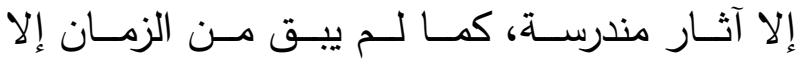

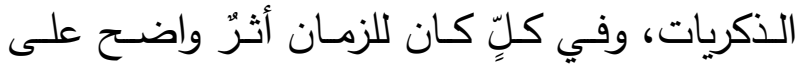
المكان، ومن الملحوظ أن اللوحة تتشكل من مفردات لترنان

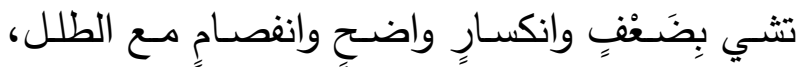

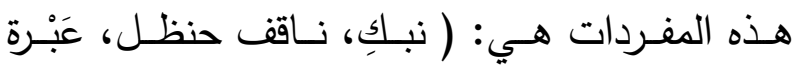
مهراقـة) ومفـردات تتضـمن معنسى الرجـاء واجـتلاب الود، والالتماس، مثل( قفا، وقوفا، لا تهلك أسىى)، ومفـردات تتضـــن معنـى الخنـوع والخضــوع، ثـم الاستسلام ثم العجز وعدم القدرة على التحدّي مثل:

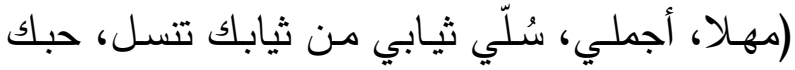

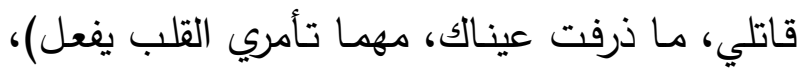
ولعل هذه المفردات تتلاحم وتتسق فيما بينها لتشكل

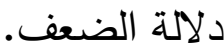
ثم يرتد مباشرة إلى مكان الحنين العارم الذي كانت

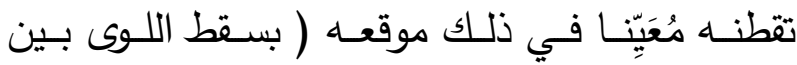
الاخول فحومل)، و ( فتوضح فالمقراة لم يعف رسمها لـمّا نسجتها من جنوب وشمأل). ومما هو لافت للانتباه أن الشاعر يوجه عنايته إلى لى له

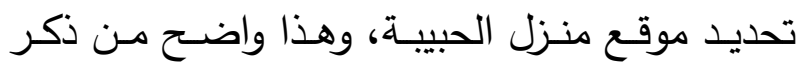
المواضع التي تحيط به، ومما هو حري بالتأمل أن 
بالأرض، لقد وضَّح هذا تركيزه على ذكراها (قفا نبك من ذكرى حبيـب...) ففي لقائهـ بالمكـان بـرزت لـه ذكراها أولا، وفي فراقه إياه أبدى عدم اهتمامه به لأنه لا يضمُّها، لقد خبت عاطفته نحوه وأصبح بالنسبة له كأي مكان آخر وأصـبح الوقوف فيـه لا يشكل أي قيمة( فهل عند رسم دارس من معول)"(10). وفيمـا يخص اهتمامـه بالمجتمع، نجده قد اهتمّ بفئة

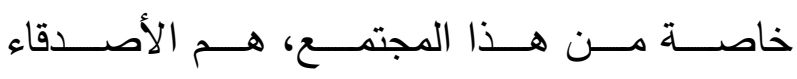
والأصــحاب(قفا نبـك..... وقوفـا بهـا صـحبي على مطيهم..) فـإذا كان هو وإيـاهم على وفـاق فإنـه لا يضار أكان المجتمع سليما سالما أم غير ذلك. لقد اتخذ امـرؤ القيس موقفـا حياديـا انتهى بـه إلى لى الإخفاق والسلب تجاه قضايا المجتمع وقد برهن بكاؤه المتواصل على النـأي بنفسـه لقضـاياه الفرديـة، وعدم قدرته على تجاوز المشكلة إلى العمل المفيد. وفي موقفه المخالف ارتدَّ في تصويره لفعاليات الحياة والمـوت، إذ كـل شـيء ينتهـي عنـــه بالعـدم وفقـدان الأمل، وهذا موقف متضـاد من الحياة والوجود، بقي تأثيره قارا في معلقته. وخلاصة القول: أن العصبية تركت فيه أثرا في نفسـا وأعطاف دواخله؛ فيبكي بكاء شديدا محاولا باستمرار استعادة بهجة الأيـام كي ينسـى، إلا أنه كمن يهرب من واقع معيش إلى الخمر · لقد كان بكاؤه بكاء متواصلا، بكى في لقائه الأطلال وفي فراقـه إياهـا، كمـا بكى لفراق محبوبته، وبكى

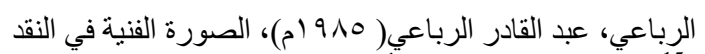

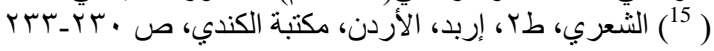

جياشـة ورؤيــة عاطفيـة للحقيقـة ( المــوت، الحيـاة/ الثابت، المتغير / الزوال، الديمومة)، لقد جمعت هذه المقدمـة بين لحظـات شتى من حيـاة نفس الشـاعر؛ فهي تشي بأنّ الشاعر يتأرجح بين حاليْن: رغبته في الحيـاة وحبـه لثـهواتها ومتعها، متعللـة بالأمـل، وهذا واضــح مـن نفْسِـهـ النزّاعـة إلـى السـعادة والإشـــاع والاسـتقرار ، أمـا الحـال الثانيـة؛ فهي شـعوره الحـاد بتشــب حـال الوجـود مـن تغيـر فـي الأشــاص والأحداث، مُشْبعة بالمعاناة والألم. وفي هذا يقول إيليا حـاوي: " وحديث الثـاعر عن الطلـل ينطـوي على بعديْن جـوهريين تتفـرع منهمـا الأبعاد الأخرى: البعد الأول هو رغبته بالحياة وحبـه لمتعها، ورغبته في الاستقرار بين أحضانها... والبعد الثاني يتولد من شعوره بهرب الأشياء وإدبارها السريع أمامـه، وحركـة التغير في الأثـاص والأحداث... ففي البعد الثاني تجتمـع - إذن - عوامـل الانقراض والهـرم والـزوال، والعوامـل التـي تُحَوّل معنـى الحيـاة وروْضـها إلـى طَلَل مُقْفِرِ مُوحش، وتجعلـه مـوطن

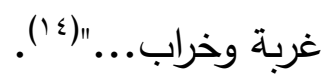
ولعل الربـاعي قد ضـرب بِمِعْوَلـه على النبـع حينمـا عقد مقارنـة بـين مقطع الأطـلال عند زهير وامـرئ القيس، ومـا يهـم الدراسـة هـو تلك التمظهرات التي تجلّت في المقدمة الطللية عند امرئ القيس؛ إذ يقول الرباعي: " لقد فَصَل امرؤ القيس الحبيبة عن المكان - الأرض - وبدا ارتباطـه بالحبيبـة أقوى من تمسكه

$$
\begin{aligned}
& \text { حاوي، إيليا حاوي ( • (9Vام)، امرؤ القيس، شاعر المر أة والطبيعة، }
\end{aligned}
$$

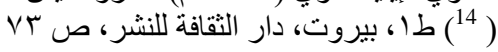


فقصيدة امرئ القيس- كما تبدو للباحث- تمثل تفرد الذات وانفصالها عن القبيلة وشعورها بالعُزْلة إلا من

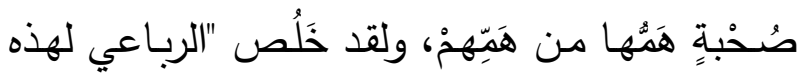

$$
\text { النتيجة" (1) - (1). }
$$

وبمقتضى هذا الأمر نستطيع القول: أن هذه المقدمة قد تبنّتْ إيحاءات نفسية عميقة، تمثلت بتفرد الذات وانشراخها عن عالم القبيلة وشعورها بالعزلة، إلا من صـحبة يجمعهم همٌّ واحد، فمن الواضـح أن المقدمـة

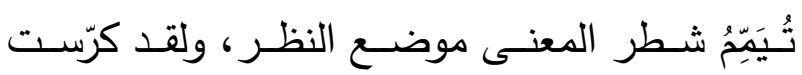
المعلقة جهدها في العبارة والجملة والتركيب والإيقاع والصـورة لتخطي محنـة الانفصـال، لكنهـا أخفقتـ، فانزلقت في غربة وانشراخ مزدوج، ومن هنا يحق لنا أن نسأل: لماذا كانت المقدمة الطللية؟ هل هي وراء تـأزم الثـاعر في شـدته؟ وهـل هـي مَحاجّهـة للواقـع المعيش في تأزبّمسه؟ ومسن هنـا نلحظ غربتين: غربـة انكفائيـة بانهزامـهـ أمـام مجتمعــه، وغربـة انكسـارية بانهزامه أمام ذاته التي بحث عنها في الماضـي فلم يجدها.

\section{المقدمة الطلاية في المُطََّّلَة ( الكلامية):}

تذكر كتب التاريخ والأدب أن قصـيدة امـرئ القيس (المُطَوَّلـة) تـأتي فـي المرتبــة الثانيــة بعـد معلقتـــه المشهورة، ولعلـه نظم هذه القصيدة في إبّان الدورة الثانية من حياته، وهي الدورة التي تعجّ بالحزن والألم

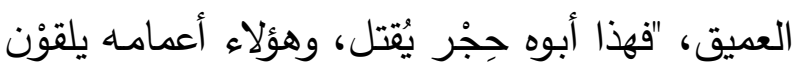
المصير نفسـه ، ومن قبلهم قُتِل جده الحسارث، وهو لقوه

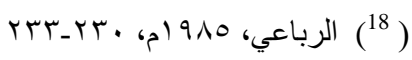

للقائها أيضـا، ثم إن بكاء حبيبتهـه هو السـلاح الذي يؤثر فيه ويصيب منه مقتلا:

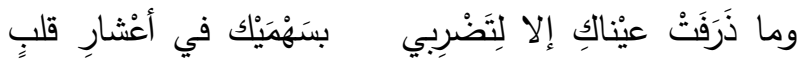
مُقَتِل الأطسلال لهذا الشـاعر هي ( المِحْنة) التي فَثِلِ في تخطِّيها، وحين تُذْكر الأطـلال عنده تذكر علاقتهـ (بفاطمة) لقد فثل في استعادة حبها، فكم ضرب لها من الأمثلة الكثيرة في العلاقات مع غيرها، وكم رسم لنفسـهـ أعظم الخطـوط البطوليـة فيهـا، إلا أنـهـ كـان يـوحي بكلامسه بكثير مـن الضـفف أمسام واحدة هـي (فاطمة)، لقد حاول جاهدا أن يلجم هذا الضعف من خلال تصسويره لأيام لهوه مع غيرها ... لمساذا ينجح مع غيرها بينما يفشل هنـا؟ إنـه الانهزام أمام الحب، وقد يكون انهزام أمـام الانسـجام والتآلف والوئـام مـع القبيلـة، وفـي القصـيدة مـا يثـي بهذا، ولعـل الاسـم باسـتغراقه الدلالي مـا يؤكد القطيعـة؛ " ففاطمـة مـن الفطيم ومِنَ الفَطْم، وفاطمـة عند العرب، هـي التي

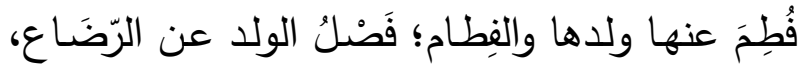
والاسم يشير إلى انقطاع الشيء عن طالبه"( ا"). وفي لوحسة الـذنبُ، تبـدو لنـا الصــورة بتفـاقم الإحسـاس بالضياع، لذا فهو يعلن بشكل صائت أنّ كلّ طرائقه في الحياة تتتهي بالضياع وعدم التواؤم، فكلاهما إذا نال شيئا أفاته، يقول: " كِلانا إذا ما نالَ شيْئا أفاتَه

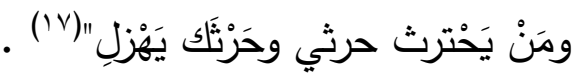

(ابن منظور ، محمد بن مكرم ابن منظور ( ع (ع (ه)، لسان العرب، طس،

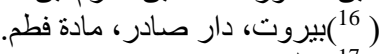

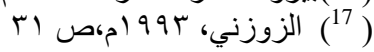


بدأ بها امرئ القيس قصـائده؛ فالاستهاللة في هذه القصيدة بدأت بـ ( ألا) وهو حرف يدل على توجيه الذهن وتتبيهـه إلى شيء هام، و" التتبيـه إلى أهميـة

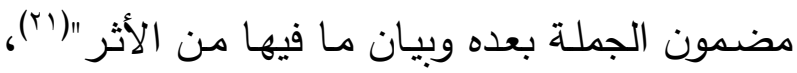
ولعلهـا - هنـا- وصـلت إلـى غايتهـا القصـوى مـن الرهافة بهذه الاستهلالة، ذلك لأن هذا الحرف ينتظم مع النغمة الحزينة- غالبا- التي تصـاحبه، وقد كان لتكثيف المعـاني في ( ألا الاسـتفتاحية) في شـعر الخنسـاء الأثـر الجلـي في إبـراز تجربتهـا الثـعرية الحزنينة، ومن هنـا فقد اعتاد شـعراء المراثي الابتداء بــه، لتصــوير بـراعتهم فـي توظيـف اللغــة توظيفـا صحيحا يعبر عن مكنون النفس، وخاصسة أن هذه الأداة تتــاغى مـع سياقات الرثاء ومـا فيـه مـن حزن وألم، تقول الخنساء:

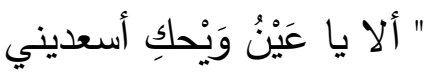

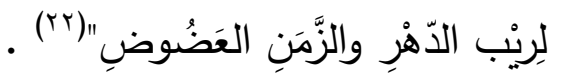

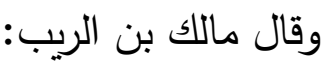
" ألا ليْت شِعْري هلْ أبِيتَنَّ ليْلةً

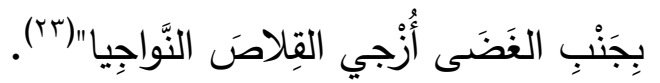
ولعلّ امـرأ القيْس افْتتح قصيدته بهذه الصـيغة ( ألا

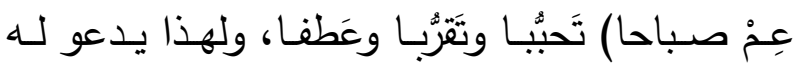
بالنعيم والسلامة من الآفات.

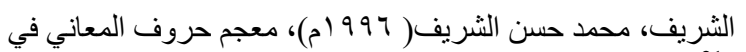

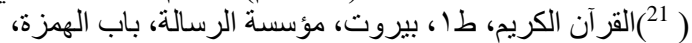

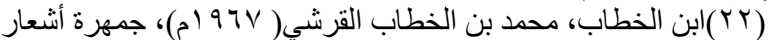

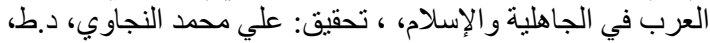

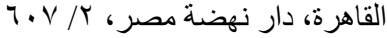

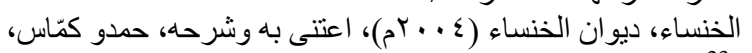

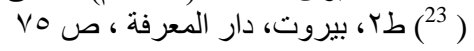

يسـى في سبيل الأخذ بثأر أبيـه، والمنذر بـن مـاء السماء يطلبه، وتتحاماه القبائل والعشائر ، وهو يتنقل

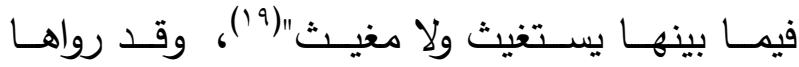

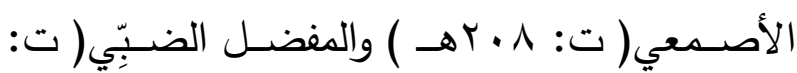
17 اهـ) وأبـو عبيد( ت: OV اهـ)، وممـا تتميز بـه طولها وتكاملها الفني، وهي التي تبدأ بقوله:

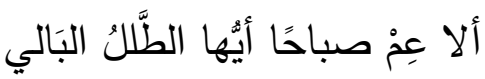
وهلْ يَعِمْنَ مَنْ كانَ في الْعُصُرِ الخالِي وليســ الدراسـة بصـدد تحليـل القصـيدة ولكنهـا كمـا حـدّدتُ لنفسـها موضـوع الدراســة، ســقتوم بمقاربــة مقدمتها الطللية، ضـمن ورشتها حول خطاب شجن الـذات مـا بـين الآلام والآمـال ضــمن تلـك العبثيـة المطلقة في فقدان المغزى وضياع الهدف والإحساس

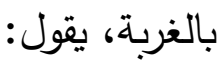

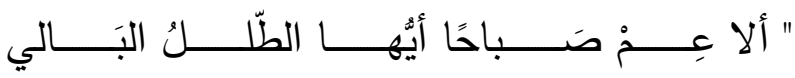
وهَلْ يَعْنَنَ مَنْ كانَ في العُصُر الخالي

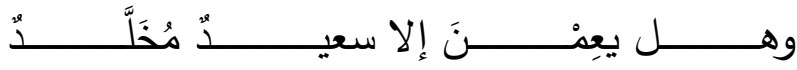
قليـــــــلُ الهُموم مــــا يبيـتُ بأؤجَـــــــالِ وهلْ يَعِدْنَ مَنْ أحْدثَ عَهْده

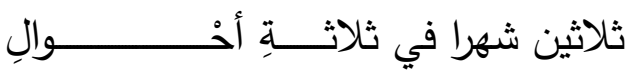

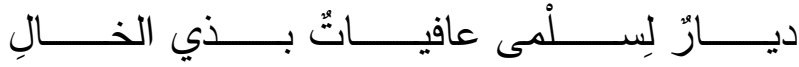

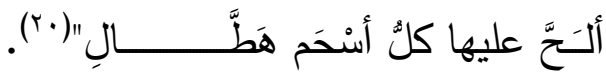
لـيس ثــة شـك في أنّ هـذه المقدمـة تختلـف في استهلالتها اختلافا بيّنا عن استهلالة المقدمات التي

$$
\begin{aligned}
& \text { ضيف، شوقي، تاريخ الأدب العربي، العصر الجاهلي، دار المعارف، }
\end{aligned}
$$

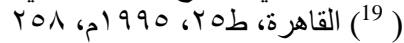

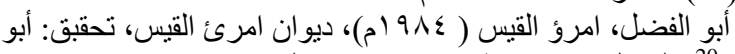

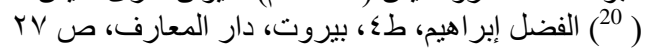


التصـالح أو التـوازن الـذي يســح لـه بتجـاوز حـال

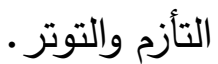

وهكذا تتشكل المقدمة الطللية من مِحْوَيْن لتتاميها:

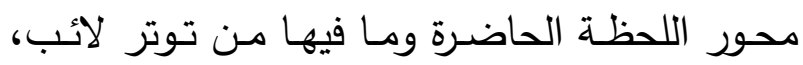

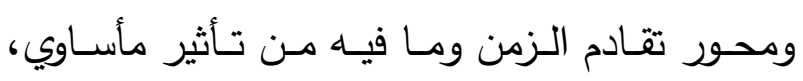
وتتمو حول هذين المحورين منشئة كلا منهما صورة متكاملـة تؤكد الدلالـة النهائية لصسورة تجسد الإدراك

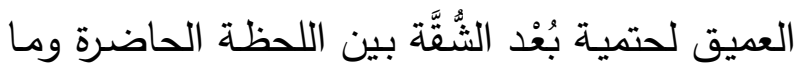

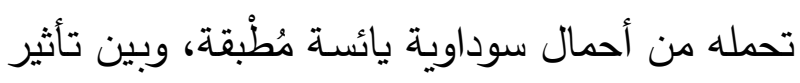

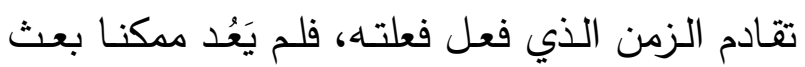
الحيوية النابضة بالقوة والعنفوان والثباب.

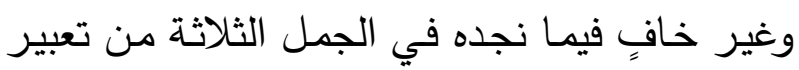

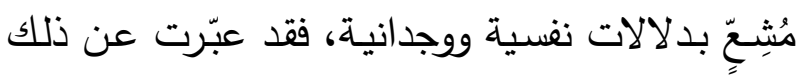

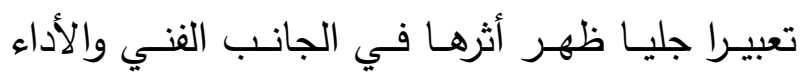

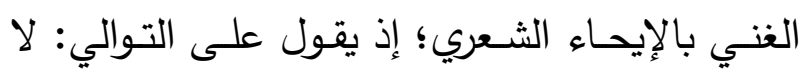

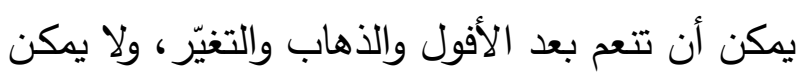

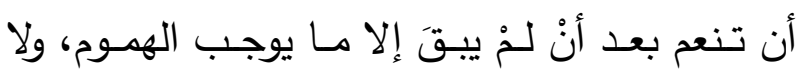

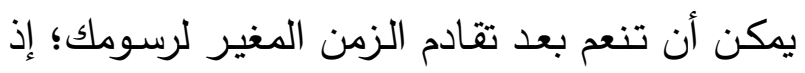

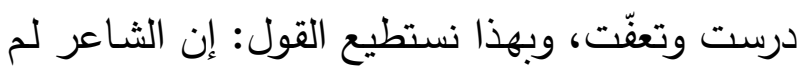

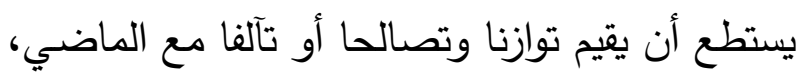

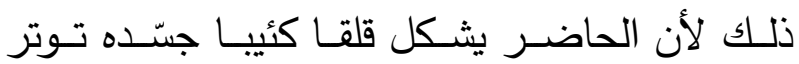

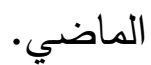

المقدمة الطللية في الأبيات التي قالها في أنقرة:

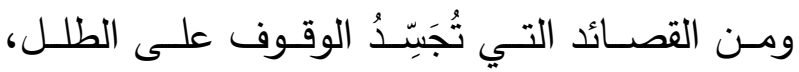
قصيدته التي قالها في أنقرة قبل موته، ويبدو الثاعر في الأبيات أنـه وصل إلى درجـة كبيرة مـن الوَهَنْ

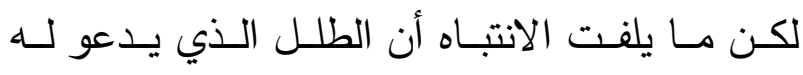

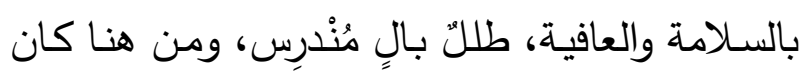
لا بد من سؤال: كيف يتواءم هذا مع منطق الحقيقة

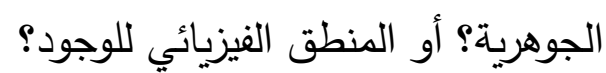
لقد حاكت القصيدة- منذ البدء - خيوطها الرؤيويـة

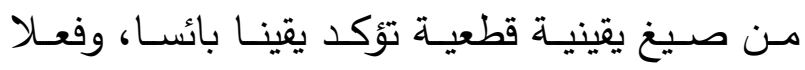
إشاريا على انقطاع الرجاء، وعدم الفائدة، وبتر النفع.

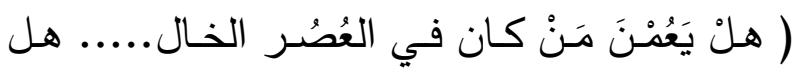

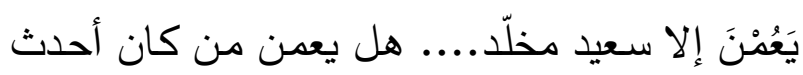
عهده..). إن جوهر الجمل الاستفهامية ليس الاستفهام، بمعنى

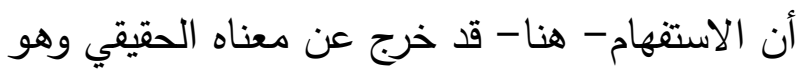

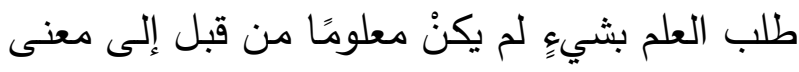

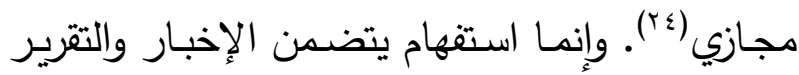
منضـافا لـه معـاني التمنـي والنفي والتشـويق وإثـارة الانتباه والاستعطاف والتوجع والأسىى؛ فالثـاعر في ولني الواقع يقول: لست أرتجي من الطلل نعيما بعد هذا والتوان

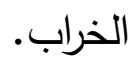
ولعل امرأ القيس يبدأ من حَنْيَّة صسارمة لا انفلات

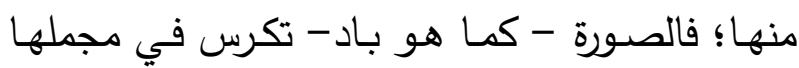

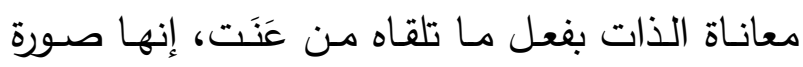

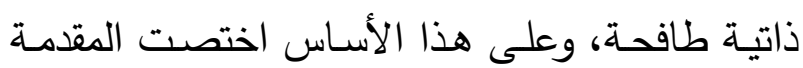

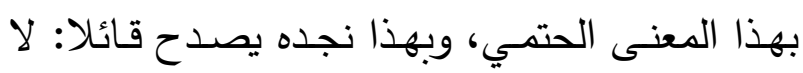

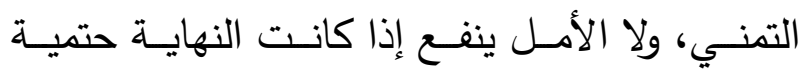

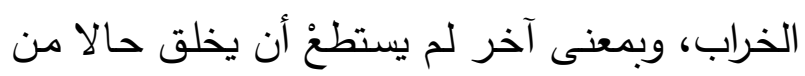

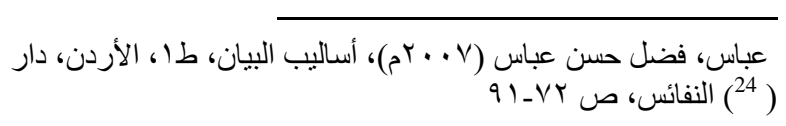


ويترتب على هذا تفريد العلاقات ورسم الثاعر صورة قصديته على نحو تتلاءم فيه مع رسوم غيره"(YV).

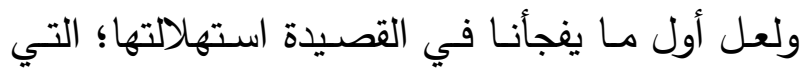

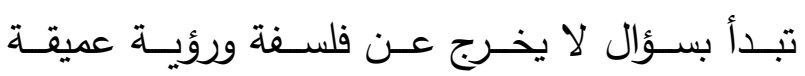
تتصـبُّ- في الأغلب- على تشـابك أبعـاد المكـان

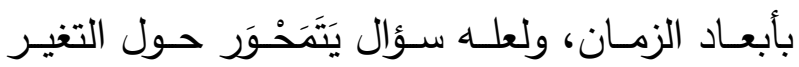
وانقلاب الحال، أو قل: تُكرّس حضورا يترجم مشاعر لئر أصداح الموت والفناء.

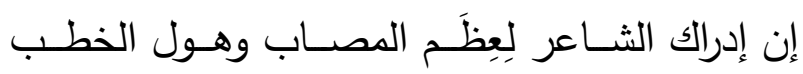
وأثرهمـا، كان وراء هذه العنايـة اللغويـة، والاستهلال بهذا السؤال، بصفته عنصرا من عناصر رثاء الذات؛ فالكلمـات كمـا يقول الجرجاني: " تقتفي في نظمها آثار المعاني، وترتيبها على حسب ترتيب المعاني في النفس"(r^). ولعـلّ المناســبة التاريخيــة التـي كانــت وراء هــــا الإبداع(9) ولتوضح جانبا مهما في فهم ظاهرة الوقوف

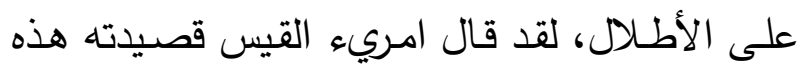

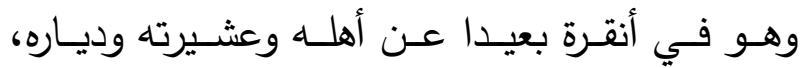

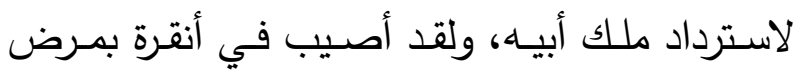
عضال، اختلفت الروايات في تحديد سببه، والقصيدة خير شـاهد على اللحظـات الأخيرة في حياة امـرئ القيس، وعلى معاناته من المرض الذي أؤهن قُواه،

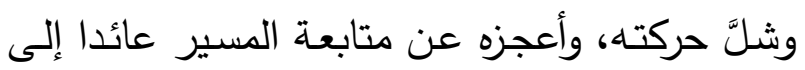

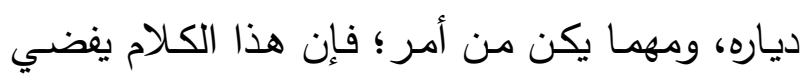

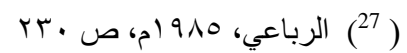

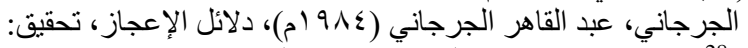

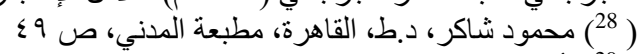

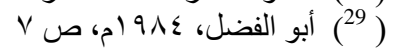

والعجز ، لم يستطع معهما أنْ يصف داءه بأكثر مما وصف:

" لِعَنْ طللُ داتثرّ آيُهُ تقادَمَ في سالفِ الأحْرُسِ تنْكِرهُ العينُ منْ حادِثٍ

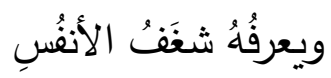

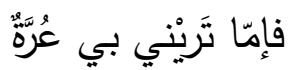

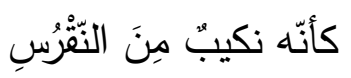
وصيّرني القُرْحُ في جُبَّةٍ تُخالُ لَبيسًا ولْمْ تُلْبَسِ

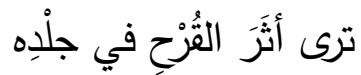

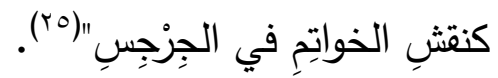

تتهض مقاربة هذه الأبيات من مستوى محاولة النفاذ إلىى ذلكـ التشـابك مـن البنـاء في أبعـاده المكانيـة والزمانيـة حـول محسور رئيس أساسـي، هـو التغيـر

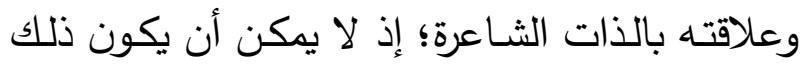

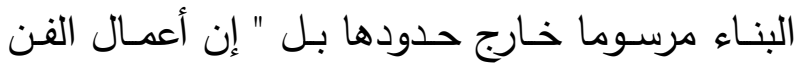

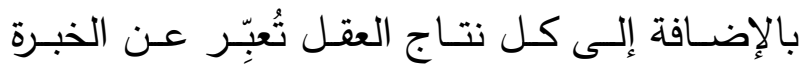
وتنظمها جماليا ورمزيا وفكريا ثم تتقل هذه التنظيمات

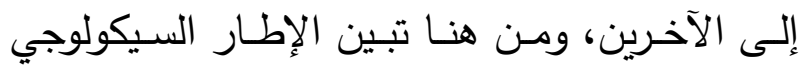

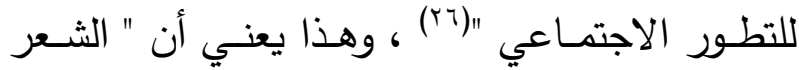
يكسب مـادة الحياة الاجتماعية شكلا ذاتيـا خاصـا،

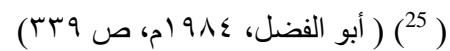

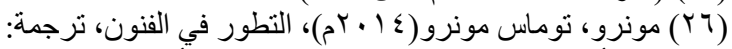

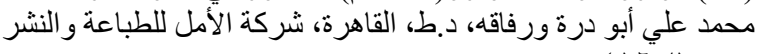


إنـه طلل تتكره العين وتعرفه النفس، والسؤال الذي يطـرح نفسـهـ هنـا: لمـاذا تعرفـه الـنفس، بينمـا تتكـره العين؟ ولعل الإجابة تكمن في أنه ينبجس من دلالة الحسال عليـه، ومسن نَفْسِ تعرف كُنْهِه وجوهره، وهذا

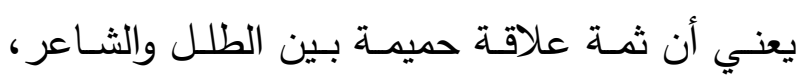
لذلك فهو يقول: إذا أنكرتهـ العين عرفته النفس، إذ هـو إلىى الـنفس أقرب، أو هـو هـي (على علاقـة التماهي به).

فالثـاعر هنا يربط بين الطلل ونفسـه في رثاء ذاته؛ فالأبيات تعكس نفس امرئ القيس وتصور حاله وهو يصارع الموت، فلا يملك له دفُعا ولا يستطيع لـه ردا؛ لذلك نجده قد نقل ضمير الغيبة في قوله: ( تتكره، يعرفه) إلى ضمير الأنا (تريني، كأني، وصيَّرني)، ثم يعود إلى ضـمير الغيبـة ليختم بها قصيدته في قوله:( جلده).

إذن ، الشـاعر هو الطلل الذي يتحدث عنـه، ولكن السؤال هنـا لمـاذا يسأل لمن طللـ؟ والجواب يتجلى من فهمنـا لأسـلوب الالتفـات الذي هو أحد المعـالم البارزة في لغـة المغتربين، يتفنتون بـه لذكر موطنه القديم وموقعـه الجديـد الحاضـر ، وهـو إلحـاحُ نفسـي

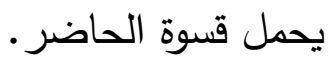

ففي غمرة الواقع ( المتغير، المدمر ، المهلك) ينبجس خيط رؤيوي يوحي بتحول ( المكان، الطلا، الشاعر) إلى معـالم تتكرهـا العين، ولكن لا يمكن أن تتكرهـا الأنفس الثغوفة، لأنها ستبقى معالم بارزة، وإن تقادم

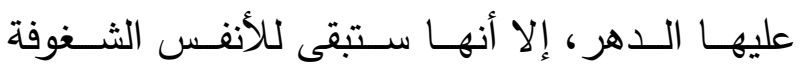

بنـا إلـى القـول: إن الوقـوف هاهنــا لـم يكـن وقوفـا تقليديا، كما أن القصيدة ليست مجرد شكل رمزي تقام فيه أنواع المشاعر كي تُنَّيها، بل هي صورة متحركة للحيـاة، تحرك فينـا قوى الإدراك لفهم أبعـاد المكـان والزمـان، ولفهـم أبعـاد الحيـاة، أو قـلـ: لفهـم أبعـاد

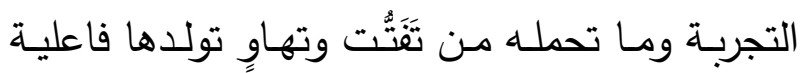
الزمن من حيث هي للتغيير • لقد كان امرؤ القيس " بصدد محاولة لفهم علاقات المكان والزمـان، والطلل وسـالف الأحرس"(·r) ـيؤيد هذا صيغة السؤال وطبيعته: لمن طلل داثر آيهُ تقادم في سالف الأحرس إنــه سؤال المضـرب الضــال، سـؤال مـن أزرى بـه الدهر ، سؤال يلقيه على نفسه بدهشة كبيرة، وهو في جوهره استيقاف الذات لصاحبها كي تعي هذا الحدث بمظاهره المختلفة، لكنه سؤال خبير ؛ إذ ينبجس منْ نَفسٍِ عالمة خبيرة بحقيقته وجوهره. والبيت في جوهره يزدحم بتشابك أبعاد المكان وأبعاد الزمـان، في محور التغير ، لقد تقـادم سـالف الدهر على هـذا الطلـل، فلـم يَعُدـ يُعْرَف ولـم تَعُدـ تعـرف علاماته، لقد بدا مَمْحُوة أعلامه. وإذا مـا قرأنـا البيت الثاني نجدنا أمـام رهاف الرؤيسة، ولا شك بأنه بيت يكشف عن خصوصية لهذا الطلل: وتنكره العَيْن من حادث ويعرفه شغف الأنفس

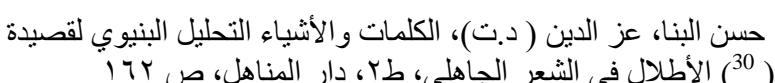


لعواطف جياشـة تلقي بظلالهها على دواخل النص ومكنوناتـهـ ، وتفيض بـدلالات عـدة ، وهـذا واضـح جليُّ مسن الألفـاظ التي تعبّر تعبيـرا صـادقا جياشـا

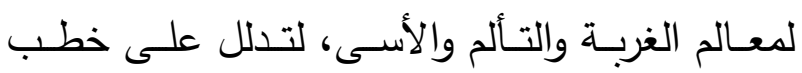
جسـيم وفاجعـة فادحـة تمسس مـن الثــاعر وجدانــه، فأعْراضُ التمزق النغسي واضـح فيها، وبخاصـة حين أحس بقرب أجلـه في ذلك المكان النائي عن أهله ووطنه:

" أجارتتا إنَّ المزارَ قريبُ

وإني مقيمُ ما أقامَ عَسيــــبُ إنب

أجارتتا إنّا غريبان ههنا

وكل غريب للغريب نسيبُ

فانْ تصلينا فالقرابة بيننا

وإنْ تصرمينا فالقربب غريب

أجَارتنا ما فاتَ ليس يؤوبُ

وما هو آتٍ في الزمان قريب

وليْس غربِا منْ تناءتُ دياره

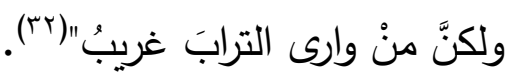

وافتتاحية القصيدة بأداة النداء ( الهمزة)، والهمزة لما وليا قرب منـك كل القرب واسـتغنيت عـن مد الصـوت، وهي هنا ليست اعتباطية أو خالية من منطق داخلي، بـل علامـة تكرس إيحـاءات الأسـى والحزن والألمّ، ويؤسـس بُعـدها الإشـاري لإيحـاءات الألم والتوجـع، والمنادى امرأة- كما يبدو - ماتت وستوارى في التراب
بمعرفتهـا، لأن المـوت يشـكل هاجسـا ملحـا وعميقـا يُجلْجل في وعي الشاعر، وهنا يتجلى لنا الإحساس بالتحول إلى طلل يكتسـب صفة الخلود لمن يأتي بعده، ولهذا لا مشاحة في أنه يذكر نقش الخواتم في الجرجس/ الصحائف.

وهذا - بالطبع - يقودنـا إلى حقيقـة جوهربـة في علم

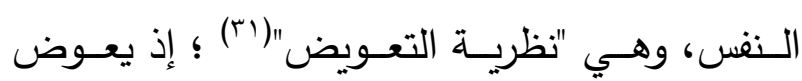
الثـاعر مـا يعتمـل في نفسـهـ مـن سـوة الإحسـاس بالغربة وقرب المنيّة برثاءٍ يكرِّس الحياة والخلود.

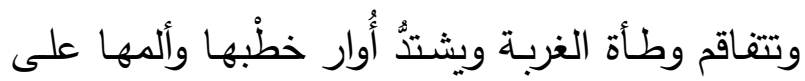
الشاعر امرئ القيس، عندما تيقن بدنوّ الأجل، ولعل مقاربـة الأبيـات الثـعريـة السـابقة تشـي باشتـاد مـرارة الحال وحرقة النفس عندما أيقن أنه سيموت في بلاد الغربة، ومن المسلّم به أن المشاعر تهتز خوفا وألما، وتعتصر النفس وتتمزق عندما يشعر المره أن المنية حلّت في بلاد الغربة. لقد عـاش امرؤ القيس مرارة الغربـة، أمـلا باسترجاع ملك أبيه، وعاش تجربتها وقاسى ألمها، ولكنها كانت أشد وطأة على نفسـه حين أحس بقرب الأجل وهو

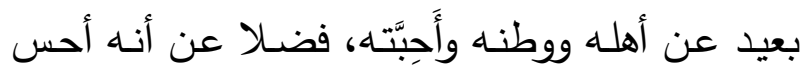
بأن آمالـه قد تلاشت وأن أمانيـه قد ذهبت، بعد أن شقي بآماله العظام. قصيدته ( أجارتنا): والمتأمل في قصيدته ( أجارتتا) يشعر بأن نبضـات قويـة حيـة لمشـاعر إنسـانية تتـفقق رقراقـة من فيضٍ

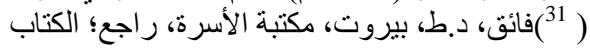


عنهما، وتتعمق فاعلية التشبث بها من خلال تكرار

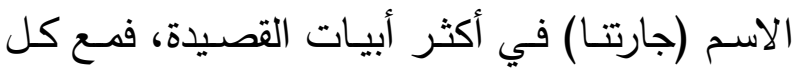

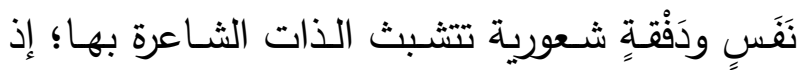

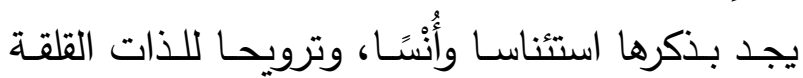

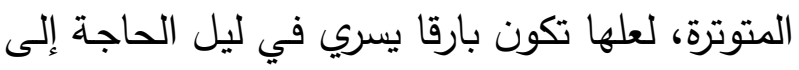

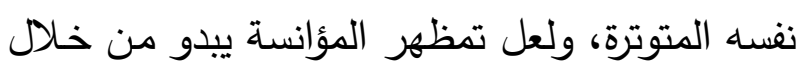

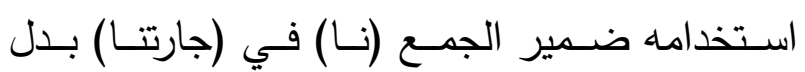

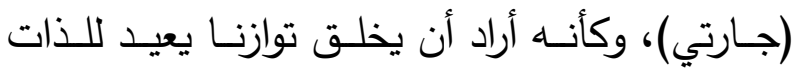
المتوترة أنسها في أحلك اللحظات وأقساها، والملحوظ أن ضمير الوصل (نا) شكل حضورا لافتا للانتباه،

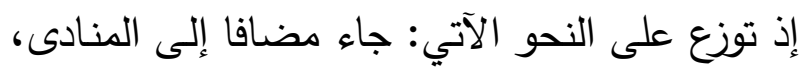

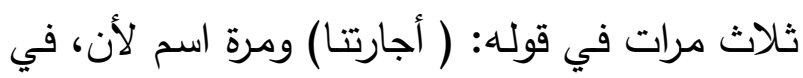
قولـه: ( إنـا غريبـان ههنـا) وجـاء مفعولا، في قولـه: (فَسِلينا، تَصْرِينا) وجاء مرة مضافا إليه في قوله:

وتعظم الفاجعة وتصبح أعمق جرحا وأبلغ أثرا، كلما أحس بقرب الأجل وأنـه قاب قوسين أو أدنى، ولذا ألذا

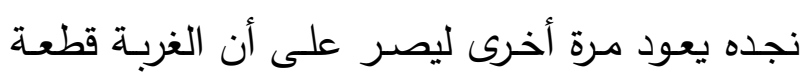

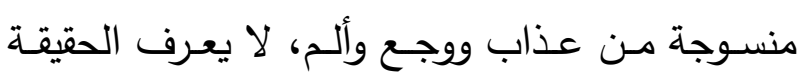
الأبدية إلا صساحبها الذي أحس بقرب أجله وانقطاع

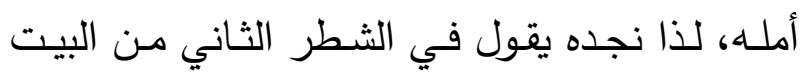
الأول : ( إنـي مقيم مـا أقـام عسيب) وهــه إثـارة

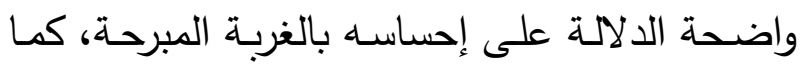

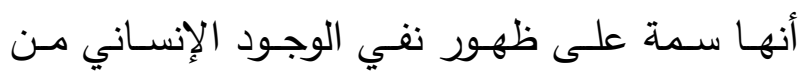

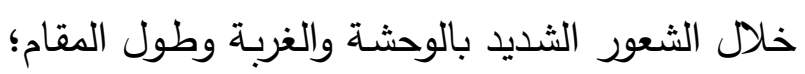

عن قريب أو أنها قد توارت في التراب، ولا أقرب من الموت الذي ينازعه قُربا من هذه المرأة.

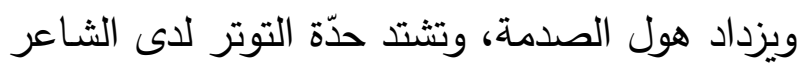
عند تيقنهـ بأنسه سـيوارى الثرى مثلهـا، ولـذا نجدهـ يستخدم لفظة غنية بطاقاتها الانفعالية، وثرية بكثافتها الشعورية( جارتنا).

يقول محمد غنيمي هلال: " إن أولى مميزات الشعر

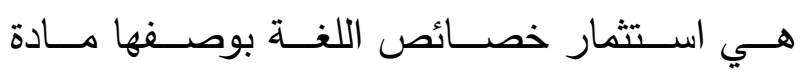
بنائية"(r")؛ "فالكلمات والعبارات في الثعر يقصد بهار بعث صورة إيحائية، وفي هذه الصور يعيد الثاعر

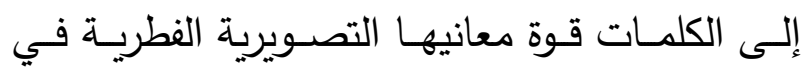

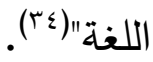
" وتشكيل اللغـة الجديدة يتأتى للشـاعر حين يتناول

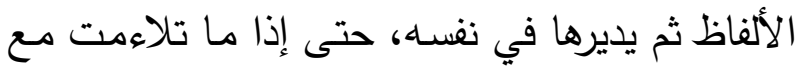

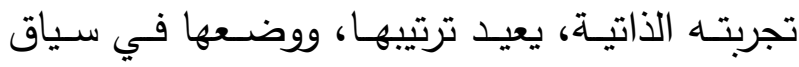

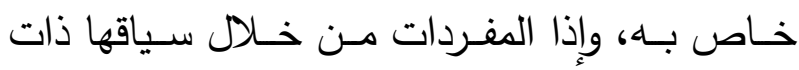
معان جديدة، تقول لنا ما لا تقوله وهي في وضعها الطبيعـي، إذ إن اســتخدام الكلمــات بأوضــــــاعها

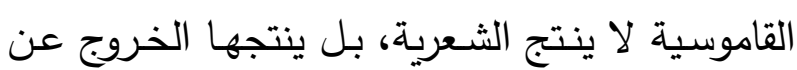
طبيعتها الراسخة إلى طبيعة جديدة"(ro).

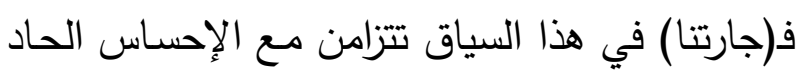

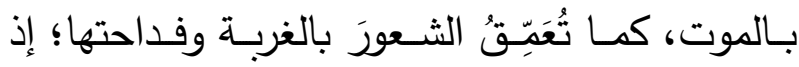
يعوض جيرتها بأهلـه ووطنـه الذين افتقدهما ونـأى لئى هلال، محمد غنيمي هلال (1997 (م)، النقد الأدبي الحديث، د.ط،

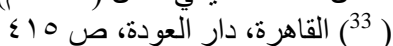

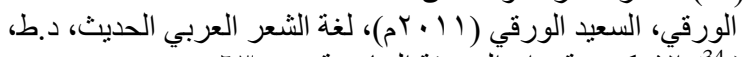

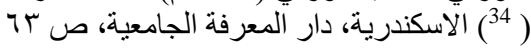

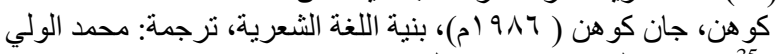

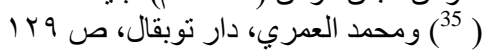


إن بناء هذه القصيدة يمكن أن يكون بناء نموذجيا

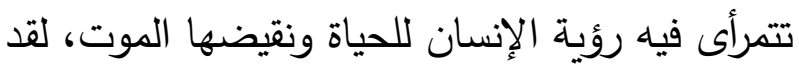
عبَّر الثـاعر عبـر رؤيسة عميقـة مـا يكتنـهـ أعمـاق الإنسـان حيال إحساسـه بالموت، لذلك نجده يطرح

القضية- في ختام القصيدة- على وجه العموم. ليس غرببـا مـن تتـاءت ديـاره ولكنْ مـن

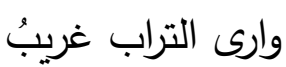
فغريب اللحد والكفن، هو الغريب بحق.

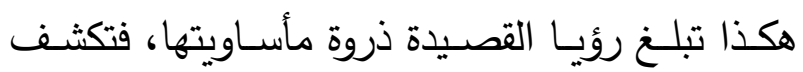
تجربة الغربة وحقيقتها الجوهرية لاى امريء القيس. الرائية ( سما لك شوق بعدما كان أقصرا):

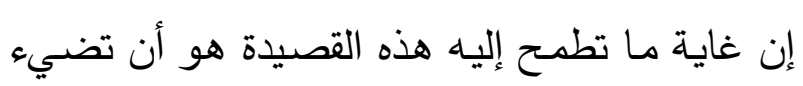
ملامح شجن الذات ما بين الألم والأمل عند الثاعر إنه مـن خـلال مـا رســته تمظهـرات البنيـة، وإمكانياتها النصية، والملابسات اللغوية التي تستحوذ على بنية

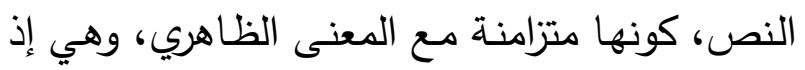
تفعل ذلك تكرِّس جهدها لرصد معطيات الاتساق في هي هني

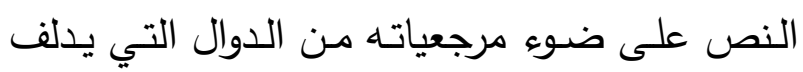
بها المشهد اللغوي.

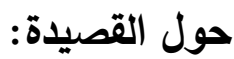
لهذه القصيدة حدث تاريخي، يدل على ذلك ما جاء

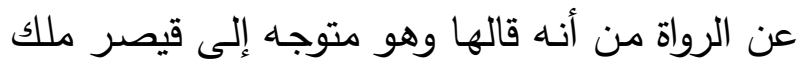

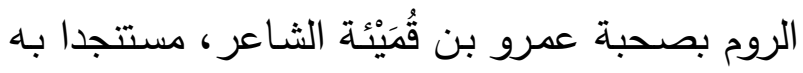
على رد ملكه إليـه والانتقام من بني أسد (بّ)، ويدل
لذا فهو قد عقد المقايسـة بينـهـ وبين مُكبث الجبـل (عسيب)؛ وهي إثارة تشي بطول الإقامة الأبدية. إن الإحسـاس والثـعور بالغربـة يـزداد فـي البيــت الثاني، وهذا يثـي بـه ذكر اسمها بلفظهـ ، وعندما

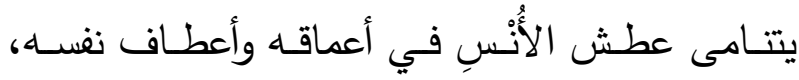
فقوله: ( كل غريب للغريب نسيب) شاهد على تدفق القي الحـال الثـعورية بعدق الحزن والألم والتوجـع، فهو يتعلق بها ويلح على أن تكون بمثابة النسيب الذي لئي يُعرِّبُ ويجمع بين المتباعدين. إن دلالمة النسـب هنـا لا تحمـل بعـا إيجابيـا، وإنمـا

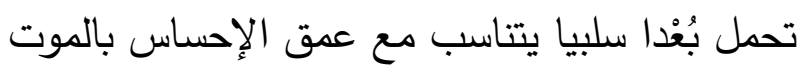
المتحقق، وعمق الإحساس بالغربة.

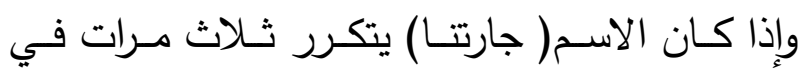
الــص، فـإن دلالتــه تجهـر بـالموت المتحقـق، لأن

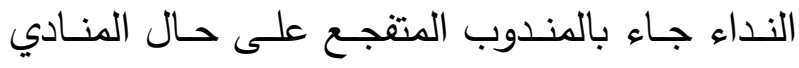
نفسه، ذلك لأن المنادي خائر القوى وفي حالة وَهَنِ وضـعف، فثــة فرق في الدالالـة بـين ( أيـا جـارتي)

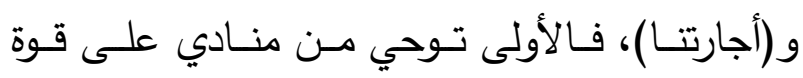

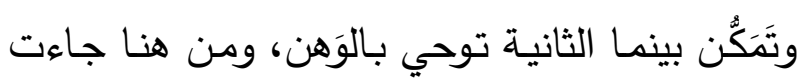
الثانية منبجسة من مَدِّ الصوت الجنائزي.

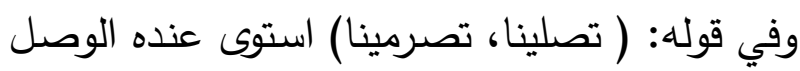
والفصل، فهما سيان عنده، ذلك لأن الموت والغربة جامع لهما لا محالة، وكأنه يقول: إنْ قبلتِ بالوصسال

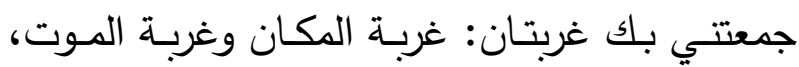

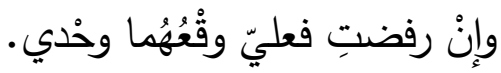


ولعلّ في استعمال الثـاعر للفعل( سما) ما يتلاءم الفي

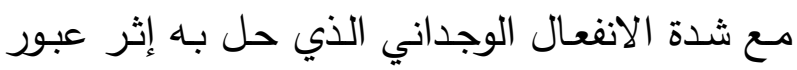
الطيف، على أسساس ما يحيل إليه تجليات الفعل؛ التهل فالسمو هنـا يُسوُِِّ العلو والرفعـة والسيطرة والغلبـة، بمعنى أن نوازع الثوق والحب والهوى غلبته وذهبتُ

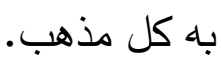

ومن الملحوظ- أيضـا- أن الثـاعر جعل المخاطبة لغيُرْه، مع أنه هو الئخاطَب، ففي قوله: ( سما لك) ما يشعرنا بأنه يخاطب إنسانا آخر مع أنه يخاطب لئه

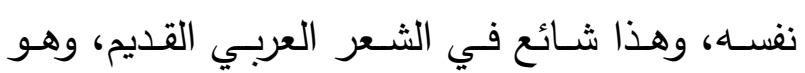

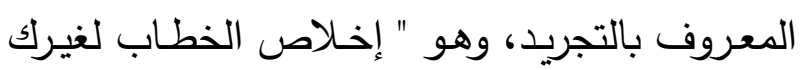

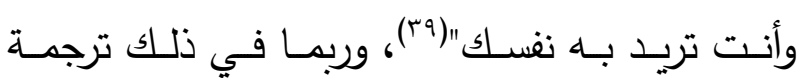

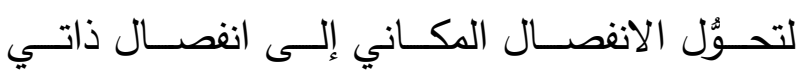
ووجـودي، إذْ تسيطر على الثـاعر هيْمنــة الغربــة وقساوته والحنين وأشواقه، لذلك نجد الأبيات الثلاثة الأولى تفيض بالألفاظ الدالـة على البُعد والغربـة

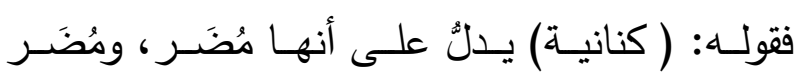

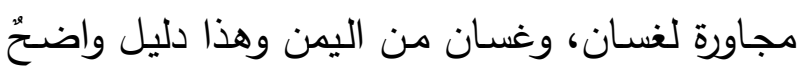
على شدة البعد والاجتماع بها، وقوله : ( بانت)؛ أي الي

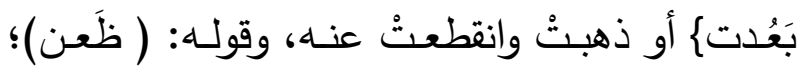

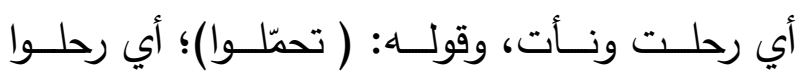

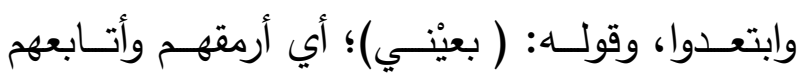
بنظري، وهذا دليل حزن لفراقهم.

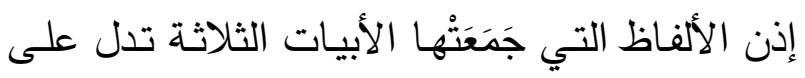
الفراق والبعد والغربة إضـافة إلى الثوق الحاد وهزّة

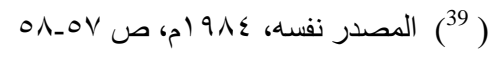

على ذلك مجموعة من الأبيات في ثنايا القصيدة،

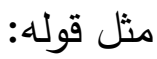

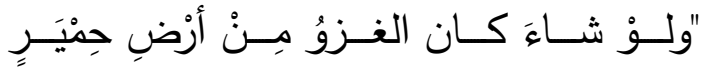
ولكنّةُ عمدّا إلى الرومِ أنْفًَا

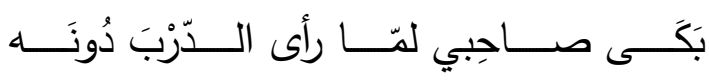
وأيَعَنَ أنَّا لاحِقان بقيْصَرًا

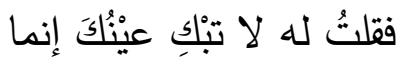

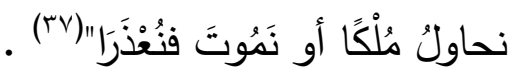
ليس ثمة شك في أن المتأمل في استهلالة التصيدة

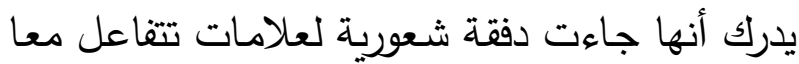

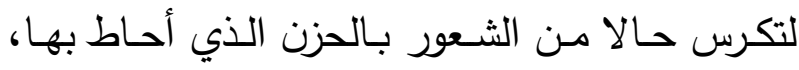
وأخذ بها كل مأخذ، فضلا عن الشعور بالقلق والتأزم الثرا، والغربـة والحزن، وهي بهذا تبــأ بالثـوق والحنين والتَّقَق إلى أرض الوطن والأهل:

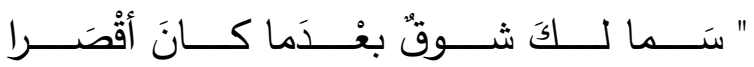

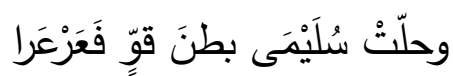

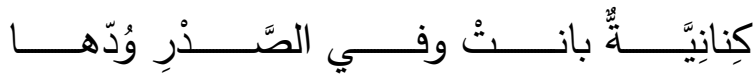

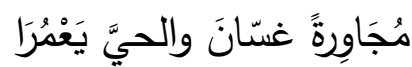

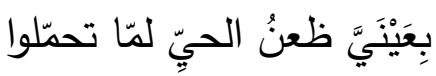

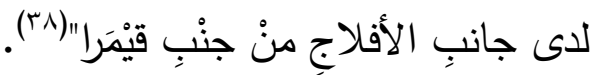
تكثف الأبيات الثلاثة الأولى الانفصـام الفيزيائي

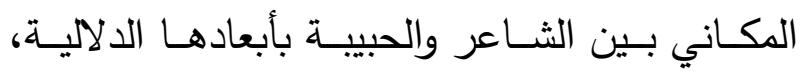

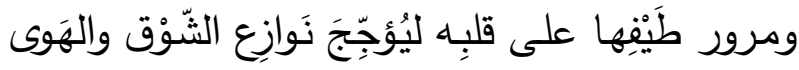
في نفسـه، بعد مـا كـان تاركهـ ومقصـرا عنـه لقربهـ 
والمَنَعَة، حفاظـا على زرعهـا وخيرهـا الكثير ، ( لقد

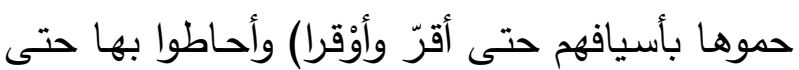
لا يضيع خيرها ويذهب لغيرهم. فالثـاعر - على مـا يبدو - ينهض على علامتين تتفـاعلان معـا في سـياق علاقـة تضــادية، علامــة تكرس الرحيل والأفول والذهاب والانفصال، وعلامة

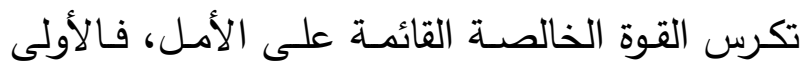
تمثل واقعـا معيثـا، والثانيـة نزعـات نفسية تختلج

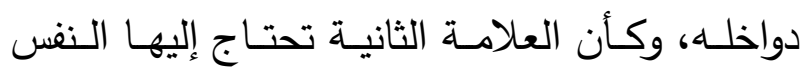

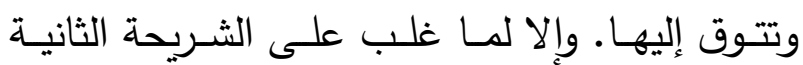
مجموعة من الصور التي تؤسس بنيان القوة والمنعة

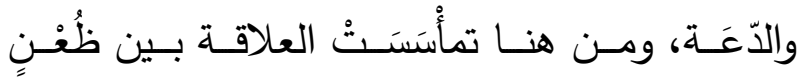

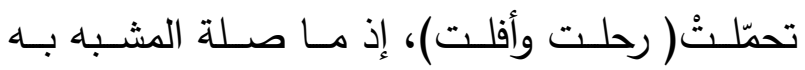
بالمشبه لولا وجود التأزم المنبجس من المفارقة التي

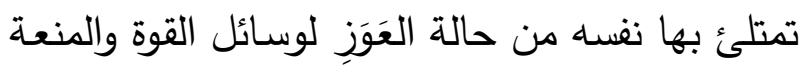

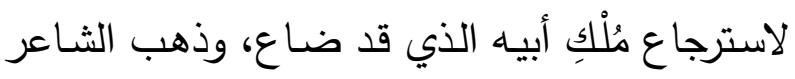
مهاجرا لاسترجاعه وإعادته لنفسه ولعهده السابق قويا

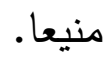
وإذا مـا انتقلنـا إلى الشريحة الثالثة نجدنا أمسام صَبٍّ

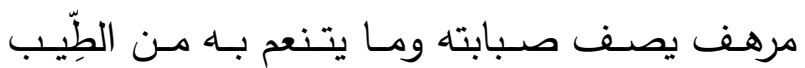

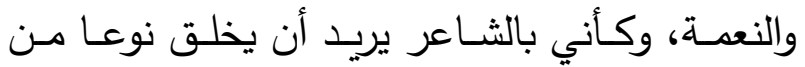

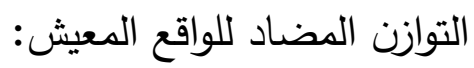

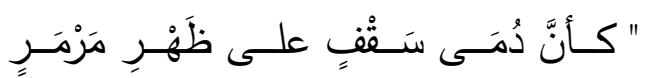
كسا مُزبِدَ السّاجومِ وشْيًَا مُصَوَرَا

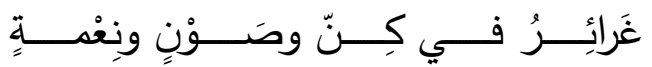
ويُحَلَيْنَ ياقوتًا وشَذْرًا مُفَفَّرا
الحنين، فضـلا عن أن صدرَه مُنتلىعٌ بحبهر وعامر بطيْف خيالهم، ثم ينتقل بعد ذلك ليصف الظاعنين إنين

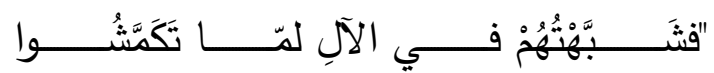
حَدائقّ دَوْمِ أو سفينًا مُقيّرا

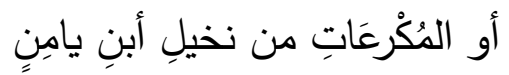
دُوَيْنَ الصَّفا اللائي يَلِينَ المُشقِّرا

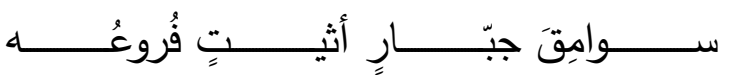
وعالَيْنَ قِنْوانًا من اليُسْرِ أحْمَرا

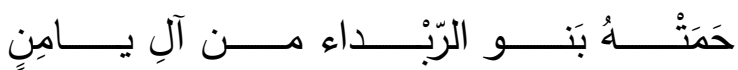

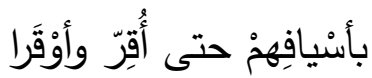

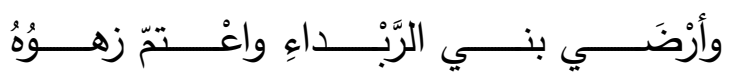
وأكمامُهُ حتى إذا ما تَهَهّرا أطافتْ به جيْلانُ عندَ قِطاعِه

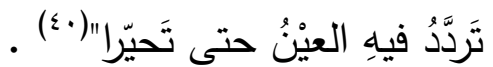

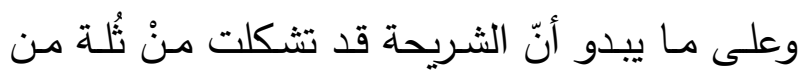
التثـبيهات الســطحية بظاهرهـا، العميقــة بمعنــاه ودلالاتها، إذ هي تشبيهات تتلاقح فيما بينها لتشكل

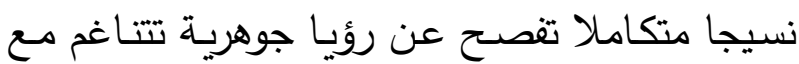
الانفعالات التي تختلج نفسه بها. لقد شبه الظـاعنين بحدائق الدَّوم الكثيفـة الممتلئة، وشبههم بالسفن المطلي ( بالقار) السائر في السراب، وشبهـهم بالنخيل الباسقات المُكْرَعات بالماء .... الخ.

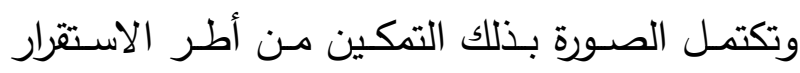

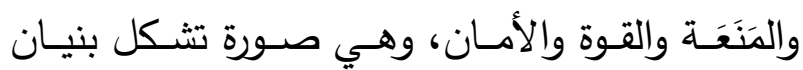

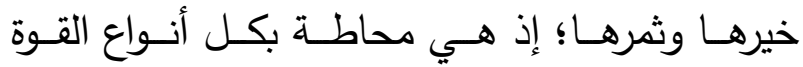

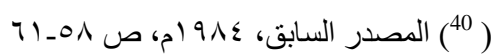




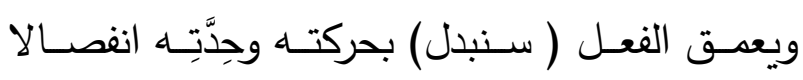

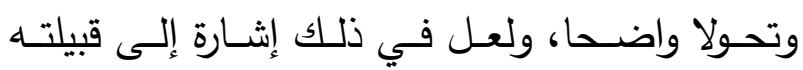

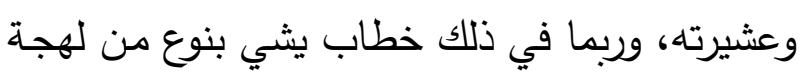

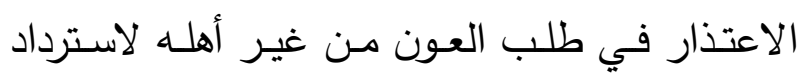

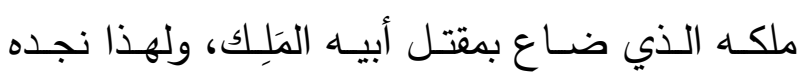

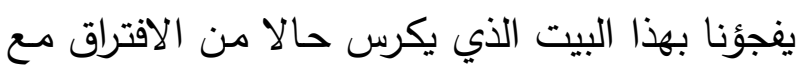

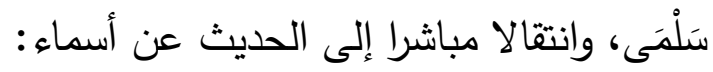
أسٔسماءُ أمُسى ودُّها قد تغنيَّا

$$
\text { سَنْبُدْلُ إنْ أبدلتُ بالودِّ آخَرا }
$$

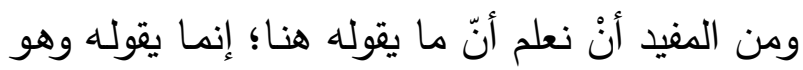
في طريقه إلى قيْصر ، ومفارقته أهله ودياره.

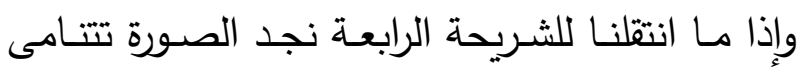
بتكاثف تجربة الغُبة وتذكر الأهل وما هو عليه من

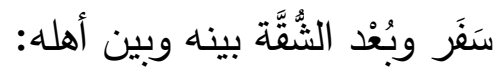

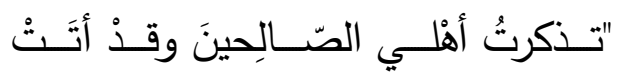

على خَلَي خوصُ الرّكابِ وأوْجَرا

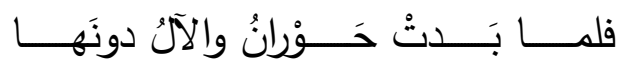

نظرتَ فلمْ تتظزْ بعِنْيَكَ منْظَرا

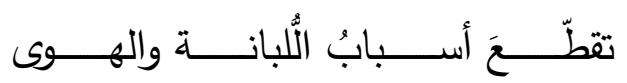

عَثَيَّةَ جاوَزْنا حَمَاةَ وشَيَيْزَا

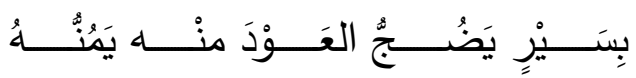
أخو الجَهٍِْ لا يَلْوي على منْ تَعَذَّرا

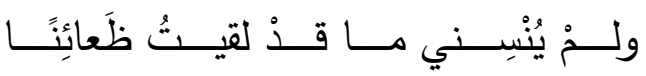
وخمْلَا لها كالقرِّ يومًا مُخَذَّرا

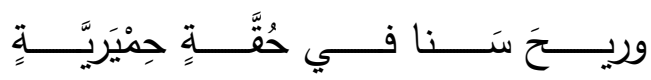

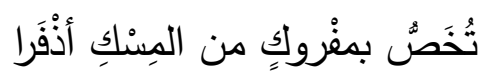

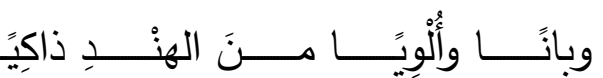

ورَنْدًا ولُبُنْى والكِباءَ المُعَفَّرا

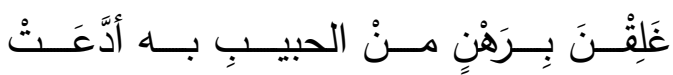

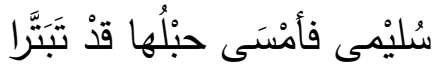

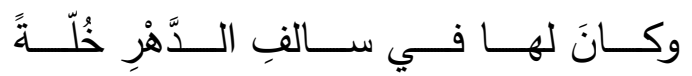

يُسارِقُ بالطَُّْفِ الخِباءَ المُسَتِّرا

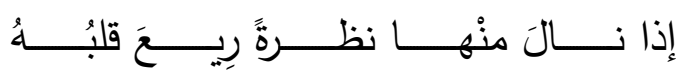
كما ذَعَرَتْ كأْسَ الصَّبوحِ المُخَمَّرا

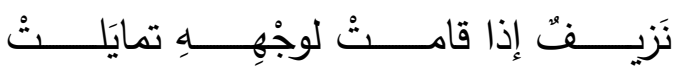
تُراشي الُْؤادَ الرََّخْصَ ألا تَخَتَّرا

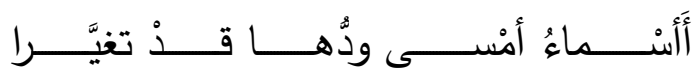

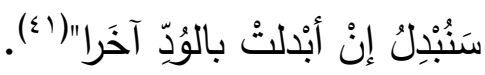

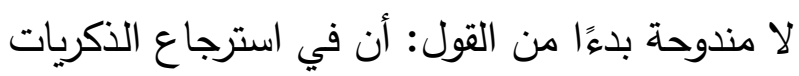

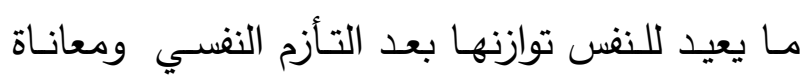

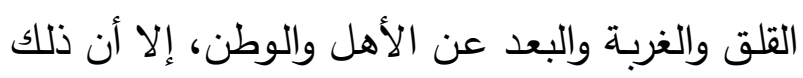

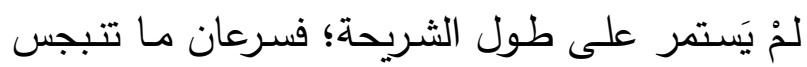

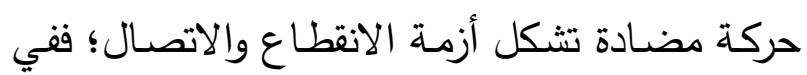

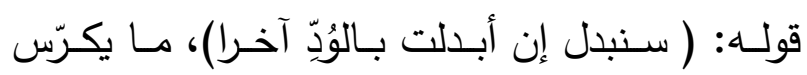

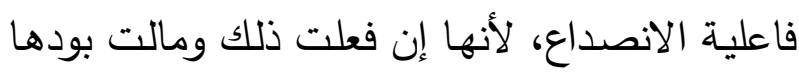

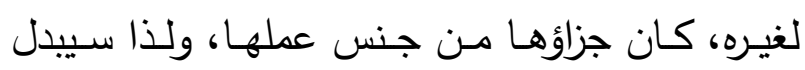

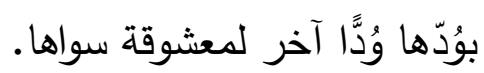

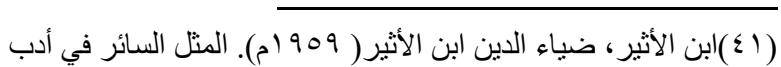

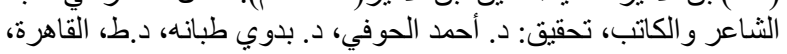

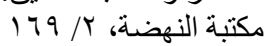


نظره- أو لعدم وضوح الرؤيسة، وهذا دليل جليُّ على مـا يعتمـل نفسـه، فالكلمـات كمـا يقول الجرجـاني: " تقتقي في نظمها آثار المعاني، وترتيبها على حسب ترتيب المعاني في النفس"(r\&). ونضـيف أن مـا يعتمـل في الـنفس ومـا يختلج في لـي القلب لا بد أن يؤثر على منطوق الكلام. وهكذا يتحقق لنا من وراء هذا التشكيل، سر عميق

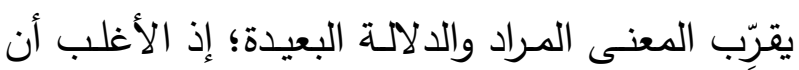
تحتل الفاعلية النفسية ما يجهر به المشهد اللغوي. ومما يزيـــ من ازدحام صورة الغربـة والثـعور بالألم، ويضفي لونـا عاطفيا حادًا هو تكرار صُوَر التذكر وعدم النسـيان، حتـى في أحلـك الظـروف، وأقسـى ولى الأوقات؛ فالثـاعر بتكراره لعدم النسيان في مواطن الوحشة والغربة والوحدة، يعطي الصورة حقها كاملا،

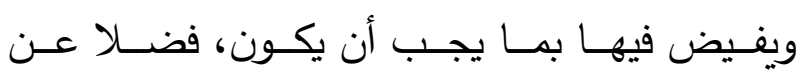
الجماليات الفنية التي تُدلف منها: ولم ينسـي مـا قد لقيت ظعائنا وخمـلا لها كالقر يوما مخدرا شربحة الناقة: ويبدو أن امرأ القيس لم يستسلم بسهولة، على الرغم مـن سـيطرة الهـم والحزن والقلق عليـه، فهو يـرفض الاستسلام والإذعان للذل والهوان، لذا فهو يقول:

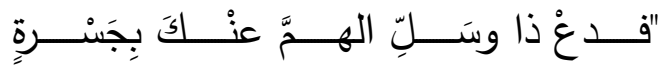
ذَمُولِ إذا صـامَ النهارُ وهَجَّرا

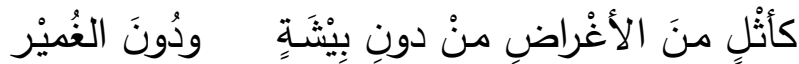

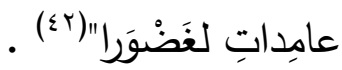
تتتـامسى الشـريحة بنسيج مـن نـوازع الشـوق والحنين؛ فـالنفس ممتلئـة بشـدة الانفعـال الفظيـع الـذي ولّداتـهـ غصـة الألم المضني ومرارة المصـاب الذي حلّ بـه، وقسوة الغربـة التي كادت تردّه عن قصده شـلا بمـا فيـه من الثدة والعنـاء، إنـا مستوحش مهروم، يشعر بالفردية والغربة، بيْذ أن هذه الغربة والفظاعة والوحدة لم تجعله يتذكر من أهله إلا من خصّهم بالصـلاح، وكأنّا به يستثني منْ تبرَّووا منه.

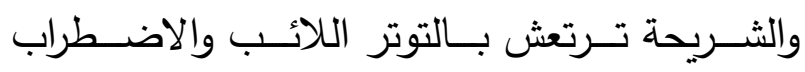
الفظيع، وتمتلئ بحدَّة ألم الفاجعة الفردية، والإحساس بالغربــة والوحشــة، فاقـدة للأمــل حتــى قبـلـل بلــوغ المُبْتِفى . فنسيج صِيَغ المنطوق، ومرجعيات الدوال التي يجهر بهـا التتاسـق والانسـجام اللغـوي، يشــي بانكثـاف الصورة النفسية التي تعتلج أعطاف نفسه. فلمّا بدتُ حَوْران والآل دونها نظرت فلم تتظر بعينيك منظرا إذ تـوميء جملـة ( فلمـا بـدت حوران) بأمـل مرجـو، لكنّ الأمـر لـم يبـق على حاله، بـل نجد المنظـر أو المشــهد قـد غطــاه السـراب ( الآل) فالرؤيــة غيـر واضحة، أو هي صورة تتبئ عن ظمآن يركض وراء سـراب يحسبـه الظمـآن مـاء، لـذلك بـدتُ لـه حـوران والآل دونهـا، فلـم يُسَـز بمنظـر ، إمـا لحقارتـهــــي في 
والبلاء والانفصام؛ فهي باستمرار حضور باهر في

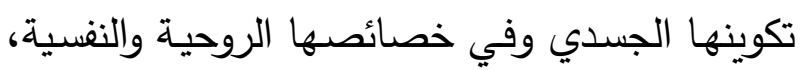

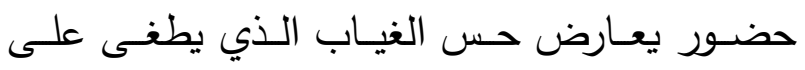

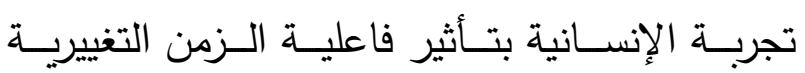

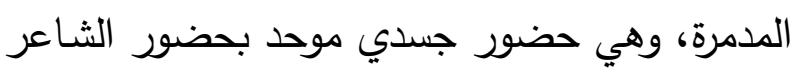
مضـاد لغياب الحبيبـة أولا، ولغيـاب الراحلين جميعـا

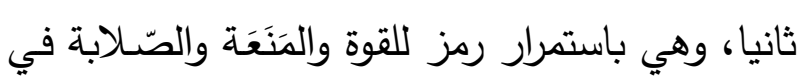

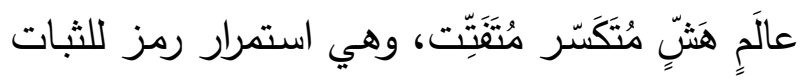
والانتصـاب الضخم الراستخ في عالم أكثر مـا يميز وفيز التغير والتلاشسي في الزمن، وهي باستمرار موحد

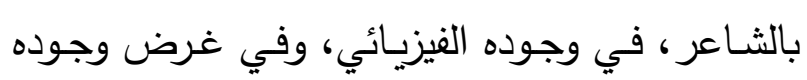

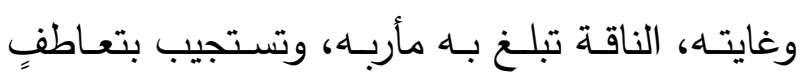

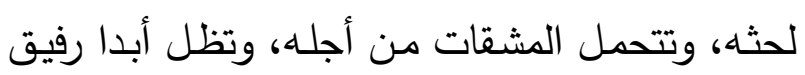
رحلته وبحثه،....، وهي رفيق وحدته في عالم تتفصم

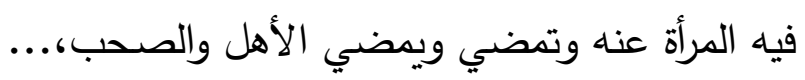

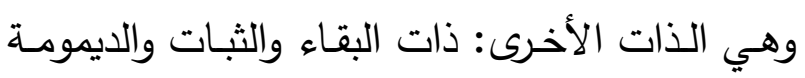

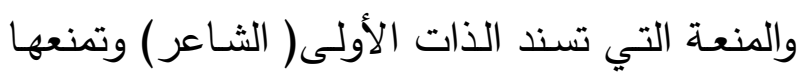
مـن السـوط الفعلـي والانــثار في غــرة الانهيـار والتتتت، إنها إبداع اللاوعي، المحتشـ بشهـوة إلقـاء

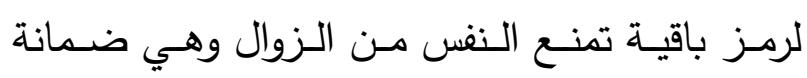

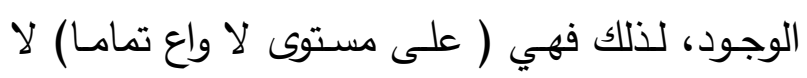

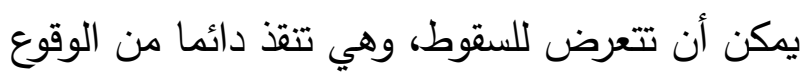
عرضة لما يتعرض له وهو الذات الأولى، لأن مجرد

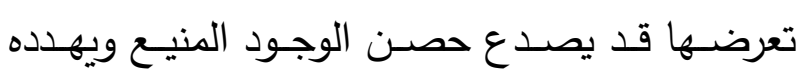
بغناء كلي، ولذلك فإنها تسربل بالحنايا يحميها ويذاد عنها، يدفنـه في العمق الصـلب الصـامد فيمـا تنـال

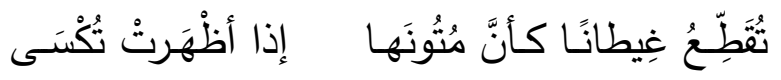
مُلاغً مُنَشَّرا بَعِيدةُ بينَ المِنْكَبْيْنِ كأنَّها تَرى عندَ مَجْرى الضَّفْرِ هِرِّا مُشَجََّرا

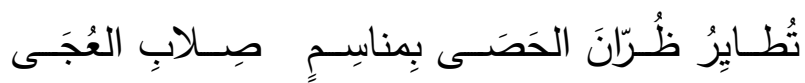

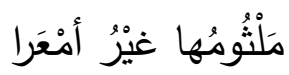

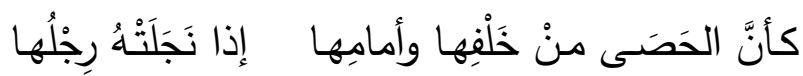
خَذْنْتُ أعْسَرا

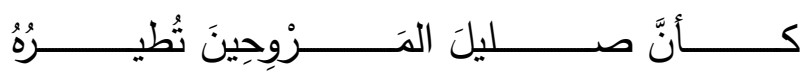

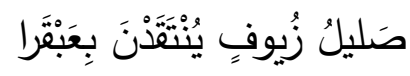

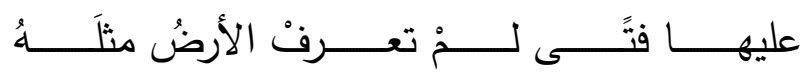
أبرَّ بميثاقِ وأوْفى وأصْبَرَا

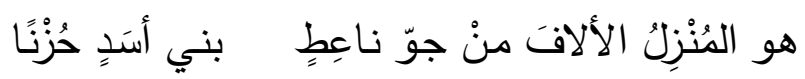
منَ الأرضِ أوَْرَا

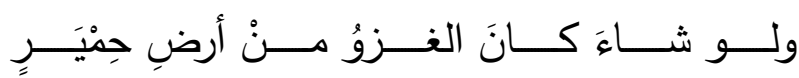

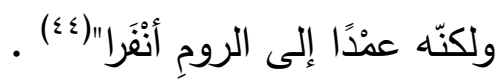

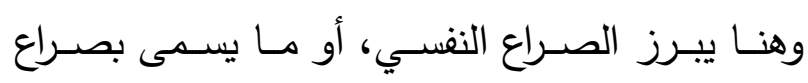

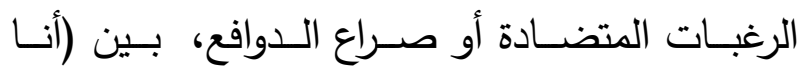

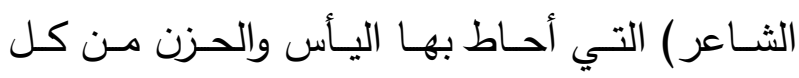

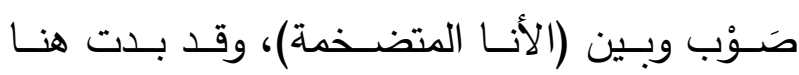
متشكلة بقوله: دع ذا.....، وفي هذا الصدد، يحدثنا كمال أبو ديب عن التجليات الرمزية للناقة في الشعر

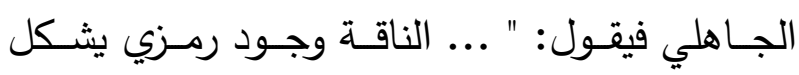
صيغة فنية لحل التناقض الداخلي الذي يسود عالم الثـاعر، والتجسـيد القـوي المضـاد للتقتـت والتغيـر

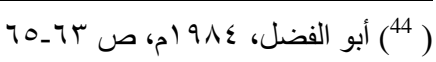


بهذه الصيغة المطلقة تماما كما أصبحت الناقة بهذه الصورة المطلقة"(7؟). فـالنص بهـذه الصــورة يتعمـق دلالـة عظيمـة على أسـاس الإحسالات لفاعليـة مفهوم الفتوة، الفتوة التي تتضـــن جميـع الخصــال السـامقة، وهـي خصــال بتوحُّدها وتما هيهـا تجمـع صـورة الناقـة الفريـدة التي تحمل هذا الفتى الفريد، وهي خصال ينبغي أن تبلغ حد الإفراط والإطلاق. ولهذا فـإن الفتى عنـــ العربـي هو الذي تجتمـع فيـه صفات الإقدام وسداد الرأي والبأس والقوة والصـلابة والمروءة، يقول طرفة بن العبد:

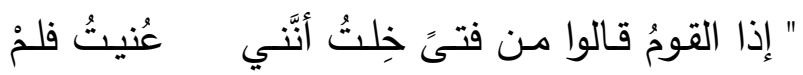

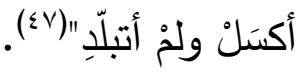
ويقول تأبط شرا، وذُكِر أن البيت لخلف الأحمر : " وفتوِ هَجَّروا ثمّ أسروا ليلهم حتى إذا انجاب حلوا"(^^). " فالناقـة بهذا رمـز التوحد في مقابـل الانفصسام.... ورمز الديمومـة في مقابـل الهشاشـة والزواليـة، وهي بهذه الطبيعـة الرمزيـة تنقل القصيدة فعلا عن حركة

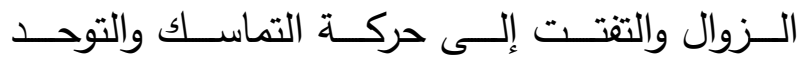
والصلابة" (9 §)

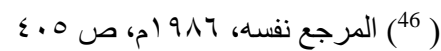

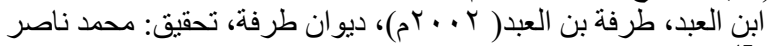

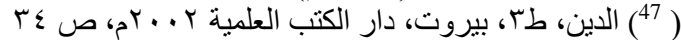

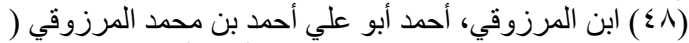

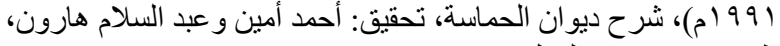

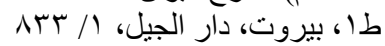
(49)

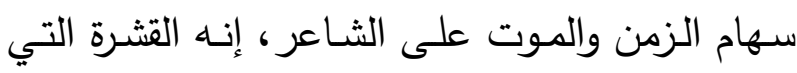

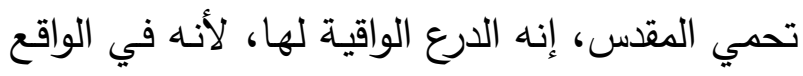
وقاؤه ودرعـه.... لذلك بالضبط تنفجر صورة الناقة في المفصل الوجودي من بنية القصيدة، حيث يبدو ودئه

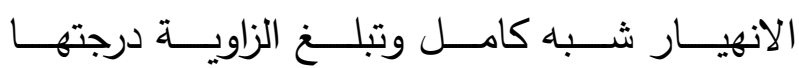

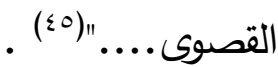
ولعل ما ذكره كمال أبو ديب يسعفنا في تجلية هذه الثريحة، ففي زحمة الرحيل وشدة الضـف وتف وتحول الظعائن في اختفاء المكان، إلى حيث لا يعلم، يردنا

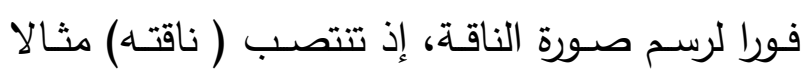

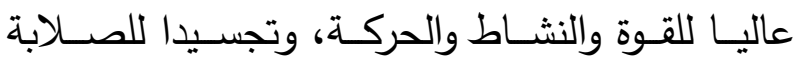
والحيوية؛ فهي منذ البداية( ذمول) سريعة الجري إذا وها صام النهار واشتد حره، تقطع السهل والوعر ، وهي بعيدة المنكبـين( واسـعة الصـدر متباعـدة مـا بـين العضدين) مكتملة الخلق متينة.

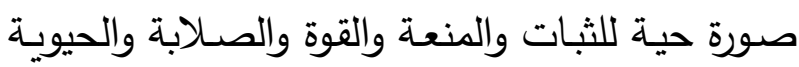

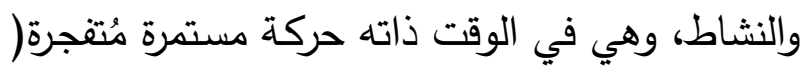

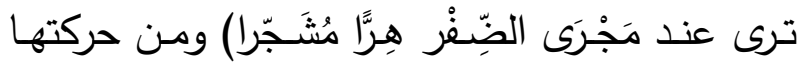
ونشاطها ونفورها وسرعة سيرها وشدة خلقها وصلابة جلدها تبدد الحصى إلى كل جهة. وتكتمل الصورة وتتعمق في أعظم مغزى لها، عندما

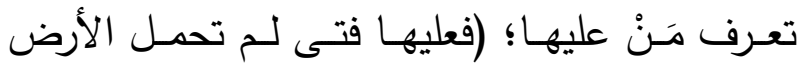
مثله) وإذ ذاك تبرز صورة البطل الفرداني الذي ينفرد بالبطولة والثجاعة والصلابة والقوة والمنعة والحيوية،

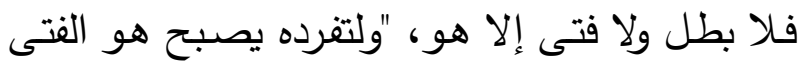
( 
ومن هنا فقد برزت الناقة في وقت وصلت فيه الحال والحوار كما يبدو بينه وبين صاحبه عمرو بن قُمَيْئة

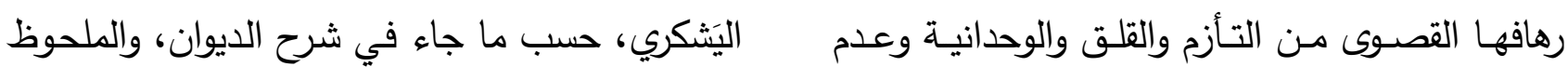

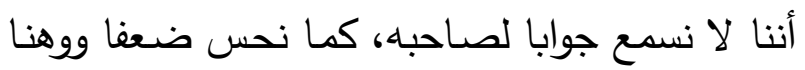
قد انسرب لصاحبه مما جعله يخاطبه ويأمره بالتجلد

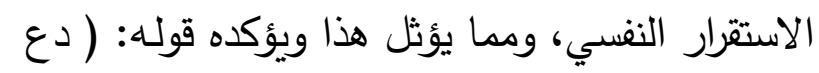
ذا وسل الهَمَّ عنك بجسرة) وهو خطاب يمثل حوارا والصبر حتى يدركا غايتهما، بالوصول إلى قيصر ، والرجوع لقتال بني أسد، فهو يقول:

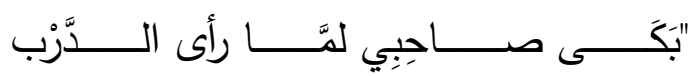
دُونَنُ وأيََْْنَ أَنّا لاحقانِ بقيْصَرا

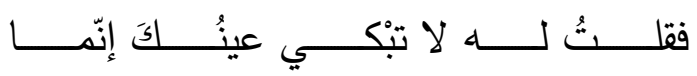
نحاولُ مُلْكًا أو نموتَ فنُعْذَرًا

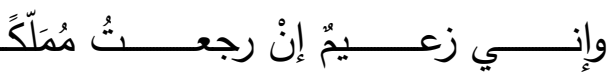
بِنَيْرٍ تَرى منْـُ الفَرانقَ أزْوَرا

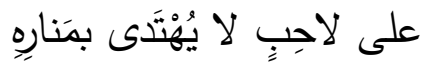

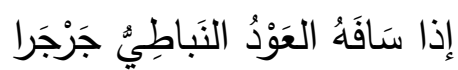

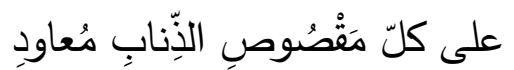

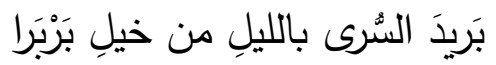

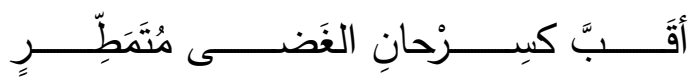

تَرى الماءَ منْ أعْطافِهِهِ قِنْ تَحَدَّرا

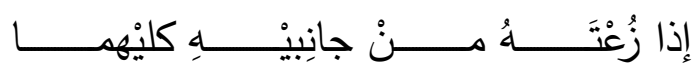

مشَسى الََهْنَبَى في دفِّه ثم فَرْفَرَ

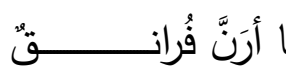
إذا قلـ على جَلْعَدٍ واهي الأباجِلِ أبنْرا"(.0).

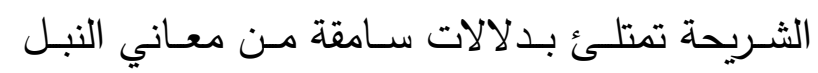
والثرف والمجد والإباء، دلالات تقيض من نفس أبيّة

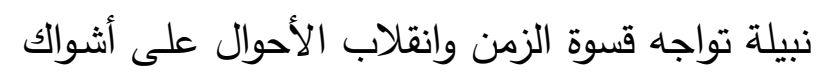

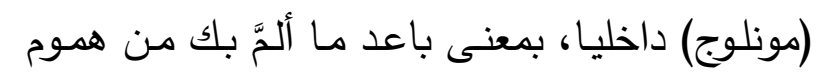

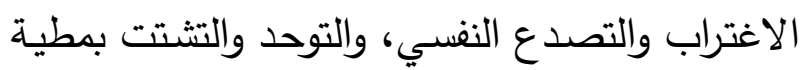

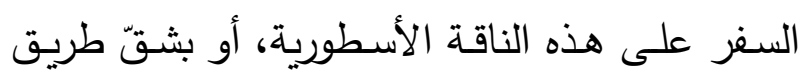

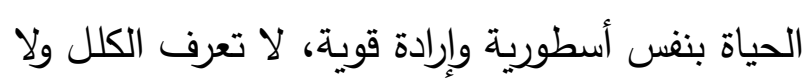

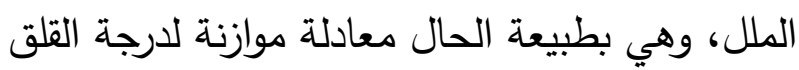
والاغتراب والتوتر والوحدة.

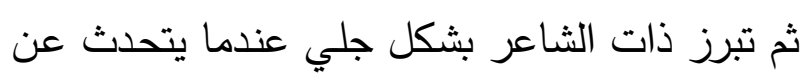

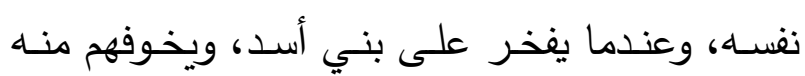

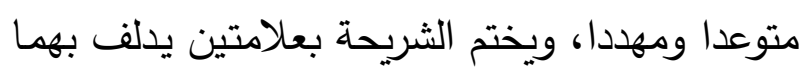

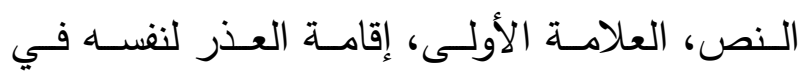
استجاد مَلِكِ الروم والاستعانة على بني أسد دون أنْ

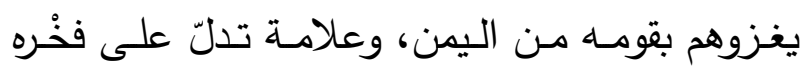

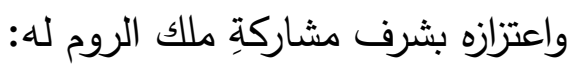

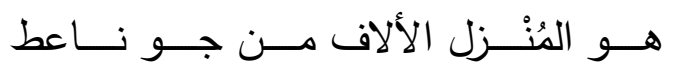
بني أسد حزنا من الأرض أوعرا

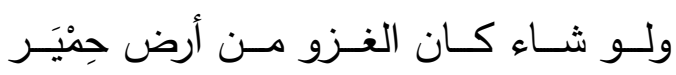
ولكنّه عمدا إلى الروم أنفرا

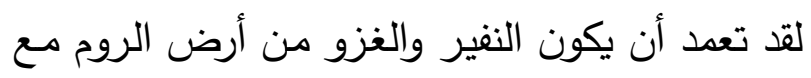
قدرته على المنازلة لبني أسد من أرض حمير بقومه لفيه من اليمن.

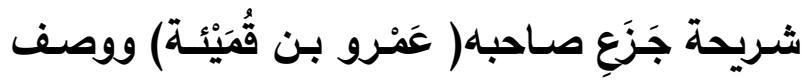
الفرس: 


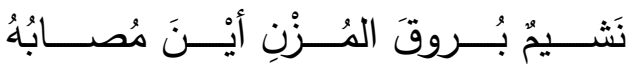

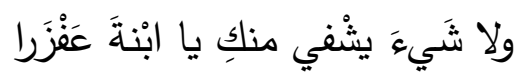

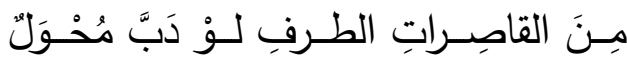

منَ الذِّ فوق الإتْبِ مِنْها لَأَتَّرًا

ولا أمٌُ هاثِـــــم

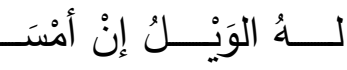

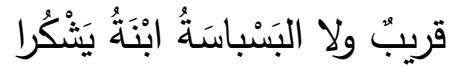

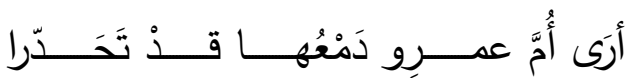

بكاءً على عمْرِو وما كان أصْبَرا

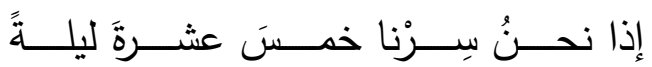

وراءَ الحِساءِ منْ مَدَافع قِيْصَرا

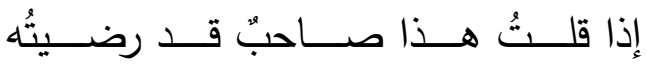

وقرَتْْ له العينانُ بُبِّلْتُ آخَرا

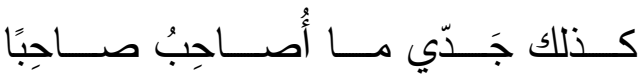

منَ الناسِ إلا خانَني وتَغَيَرًا

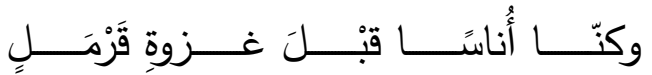

ورِنْنا الغِنى والمَجْدَ أَكْبرا أَكْبَرا

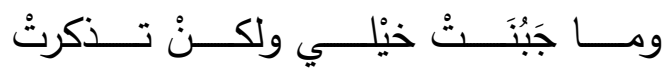

مرابِطَها منْ بَرْبَعِيصِ ومَيْسَرا

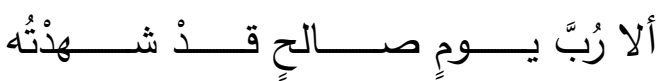

بتأْذِفَ ذاتِ التَّلِّ منْ فوقِ طَرْطَرَ

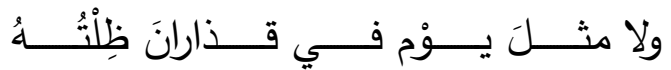

كأنّي وأصْحابِي على قَرْنِ أعَغْرا

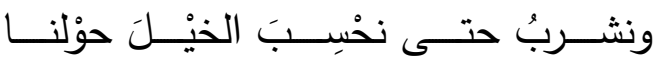

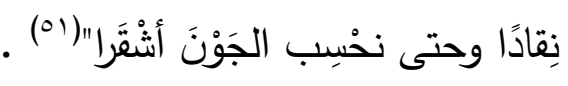

الثِتِّة والغربـة والمحنـة؛ فالثـاعر يدعو صـاحبه أن

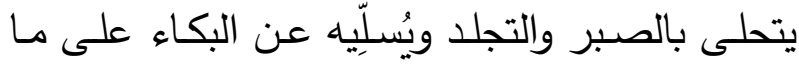
يجد حتى يبلغا ما مبتغاهما، وهو في الوقت نفسـه

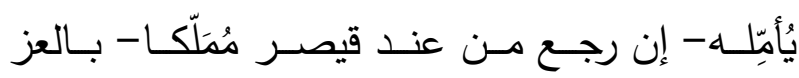

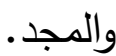
وهو في هذا يعالج قلقا وهمّا آخر ، وهذا- أيضـاينضاف إلى حدة الثعور بالغربة والتيه التي يعانيها

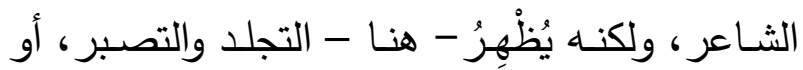
يدعو صاحبه للتجلد والصبر ، وهي بلا شك دعوة لنفسـه بالتجلد والتحمـل والصبر على عنـاء السـر وأثواك محنة الغربة وقلق المجهول. وفي اللوحـة يبدو تزاحم صـور الخيل، وهي صـورة

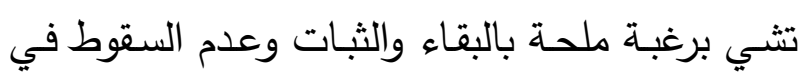
غــرات التشـتت، وهذا منبجس مـن علاقــة اللوحـة بالبؤرة الجوهريـة التي يدلف منها النص، وهي خلق مهد التوازن بين حركتي التشتت والتماسك، وبين حركتي الرجوع عما كان عليه والثبات على الإقدام، ولهذا تسيطر على ساحة المشهد دلالات تحمل أملا مرجوا

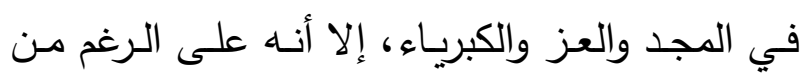

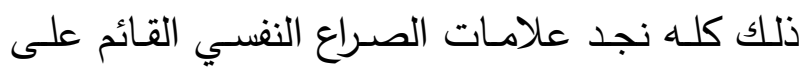
الأمل والألم يتكاثف في خيال الثاعر ، وبخاصة في شريحة شكاية الحال. شريحة شكاية الحال وذكر المآل؛ البكاء على الأيام

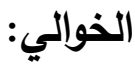

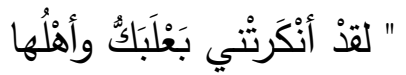
وَلابنُ جُريْجِ في قُرى حِمْصَ أَنْرَا 
أو لواقع مجهول آت، وبهذا يكون هذا الفيض من

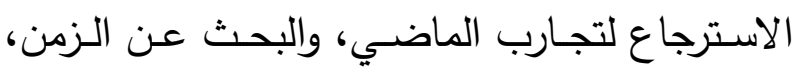

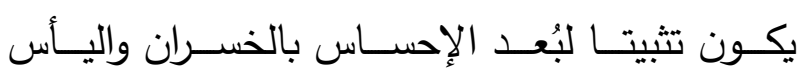

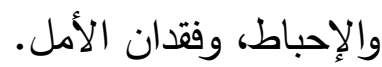

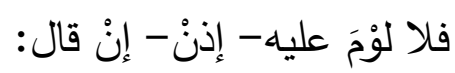

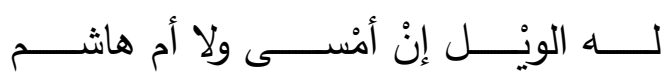

قريب ولا البسنباسة ابنة يشكرا إنه الشعور الحاد والتوتر الثديد بالنأي والبعد.

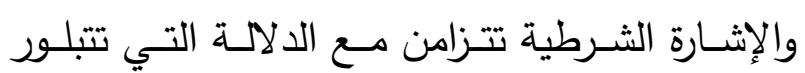

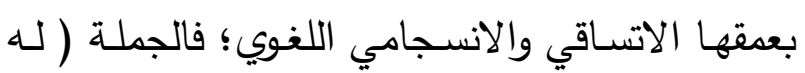

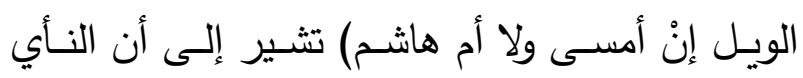

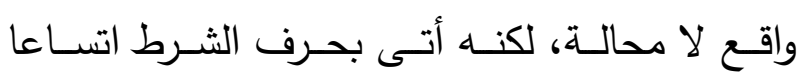

ومجازا وإيهاما ومبالغة، وهذا يشبه قول الفرزدق:

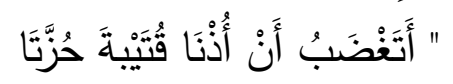

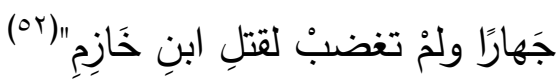
واقع ولكنه بالشرط كما ذكر .

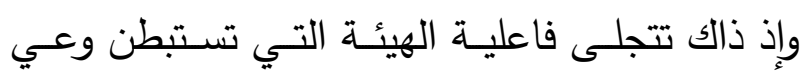
الثـاعر عمقـا بوسـاطة جملـة الثـرط، كمـا يمكنتـا الظفر بإيحاءات ضمير المتكلم الذي استتر بضمير

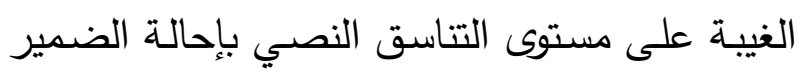

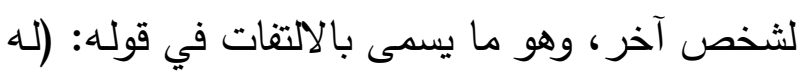

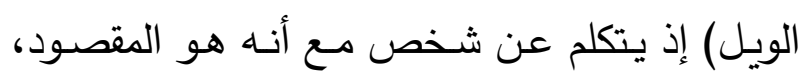

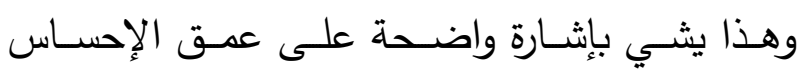
بالنأي والبعد والإحساس بالغربة الثديدة.

الفرزدق (9AV (9 م)، ديوان الفرزدق، شرح وضبط: علي الفاعوري،

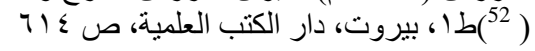

وفي تزاحم حياة محفوفـة بأشـواك الغربـة والبعد عن

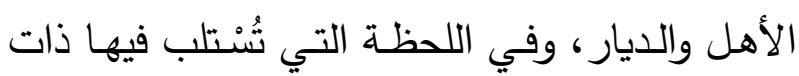
الوجود الإنساني بالاغتراب، والثعور بالضياع، وفي وفي لإني الوقت الذي تصبح فيه الذات نكرة مبهمة في مكان غير مكانها، وأهل غير أهلها وديار غير ديارها، أو

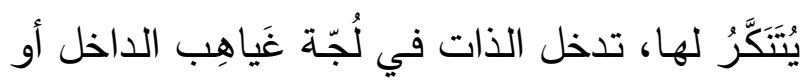
تتكفي على نفسـها لتطل مـن خلالـه على بـوارق

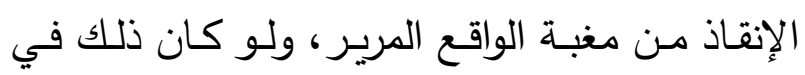
سماء الخيال، لعل في ذلك تسلية أو إعادة لتوازن الذات القلقة المتقهقرة والمتشتتة في ديار الغربة.

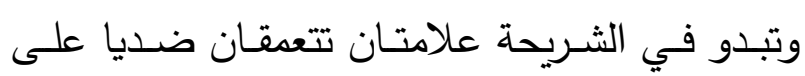
أساس ما تحيل إليه فاعلية كل منهما؛ فالفعل (أنكر ) يسـوغه ملـؤ القلب بـالتقلق والغــم والكـرب والثــور إليه

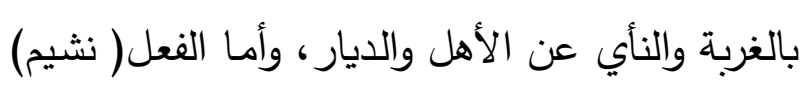

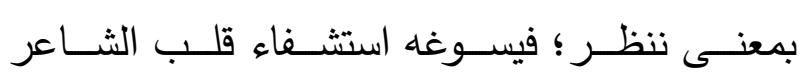

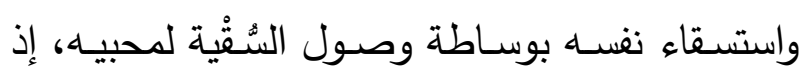

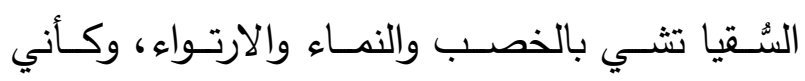

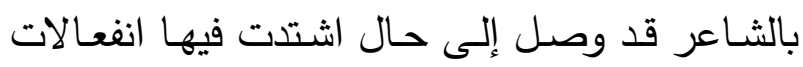

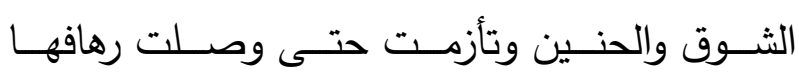

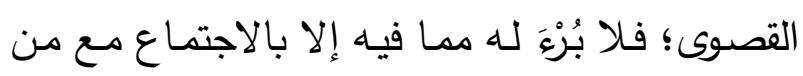
يحب، كما لا ارتواء ولا خصب ولا نماء ولا حياة إلا بلا لهاجي ببلوغ اللُّقْية ووصولها إلى ديار من يحب ولاء (ولا شيء يشفي منك يا ابنة عفزرا).

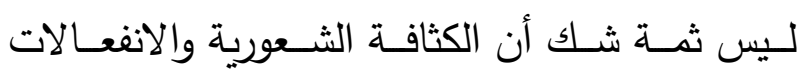
الوجدانية تستحوذ على ذات الثاعر ، ولعلها محاولة خلق حال من التعادل المضـاد لواقع صعب معيش 
الشرب التي يذهب السكر بها عقله، كل ذلك افتخارا واعتزازا بالماضي، وتعويضا عن تلك الهزائم، وحقيقة لحظة الواقع المعيش. وفي مقابل هذه التقصيلات للماضي الضـائع، نجد

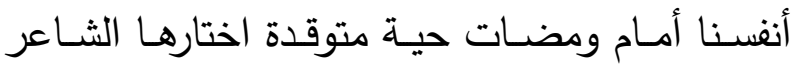

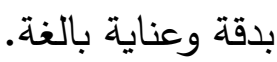
وبسبر أغوار النص يتجلى لنا دقة اختياره للمفردات، باتها،

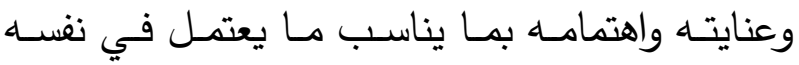
واستخدامه لوقعة ( قرمل) التي خسر فيها المعركة كلمة غزوة بقوله: ( غزوة قرمل) بينما بقية الَوَقَّات

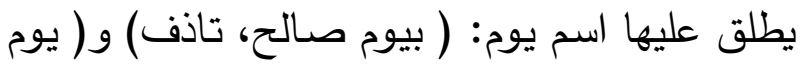

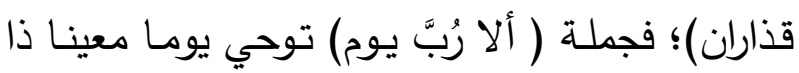

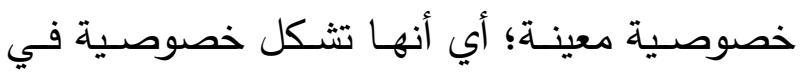
ذات الثـاعر، واليوم بالنسبة لـه يكرس خصوصية معينة، كما تظهر صفة اليوم في قوله: ( يوم صالح)

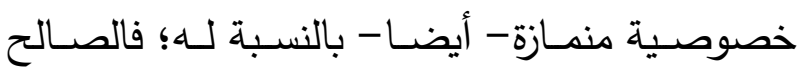

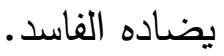
وغاية ما يُطمح إليه هو الإثارة إلى أن اللوحة تثكل بفاعليتها استرجاع لحظات الزمن وهو يمر بـه، لأنها لحظات تمتلئ بها نفسه، وتشكل - بحدتها - القوة المضـادة لواقع معيش يمر بـه، واقع الغربـة والفقدان والانكسار والألم والتغير ... الخ. شربحة الحَيْرة:

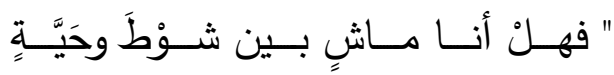
وهلْ أنا لاقِ حيّ قيُسِ بنِ شمّرا
إلا أنه سرعان ما يبرز ذاته عندما يتكلم عن نفسها

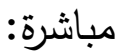
أرى أم عمرو دمعها قد تحدّرا بكاء على عمرو وما كان أصبرا فتجليات تمظهر الذات سرعان ما تتكشف ظهورا جليا في الفعل ( أرى) مـع أن الضـمير مستتر في في في

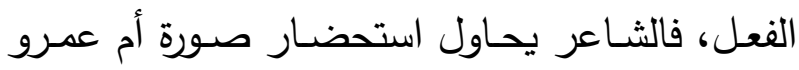
وهي تبكي، وكأنه يعطي الأمر جُلّ عنايته واهتمامه، كما يحاول عدم ازدراء نظره عنها، ليشاركها الحزن عليه. لا شك أن الثريحة تثي بإحساس الانكسار والثعور بالقهر ، لخذلان الجميع له، وتخليهم عنه، ولكنه بين

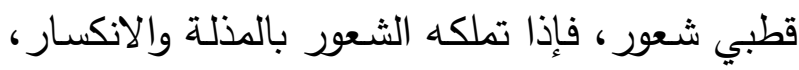
حاول العمل على التخلص منـه، لذلك تجده عندما يذكر موقعـة ( قرمل) يجد لزامـا عليه أن يتذكر مـا كان قبلها، فيتغنى بشرفه الأصيل ومجده التليد، فهو لئه

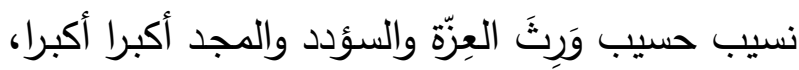
ولم تلحقه منقصة ولا ذم، وعندما يذكر وقعة (قرمل) التي كانـت مؤلمـة، يحساول أن لا ينحنـي لتأثيرهـا

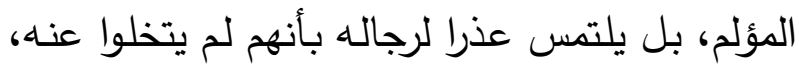

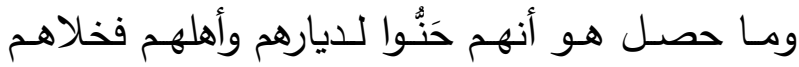
ليرجعوا إليها، ثم يفيض بالحديث عن يوم (تاذف) ذات التل، الذي اطلق عليه اسم يوم صـالح، إيماء إلى الظفر الذي أنجزه، كمـا يذكر يـوم (قذارات)

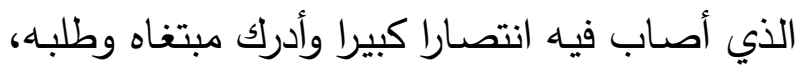
كما أنه لا ينسى ذكر أيام النشوة والابتهاج، وساعات 
الخصوصية، والفردية في هذا الموقف مـع كل كلمة منها؛ فهو يخوض تجربة فريدة نادرة متميزة، لذا تعلو نبراتها في حسال شعوره بـالقوة، وتنخفض في حسال ضعفه، لكنّها توحي بمدى الانكسار والثـور الحاد

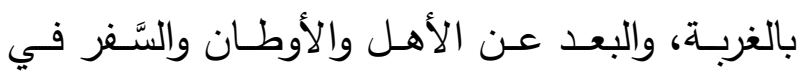
المجهول.

\section{خاتمة الدراسة}

خرج هذا البحث بنتائج يمكن إجمالهـا في النقـاط الآتية:

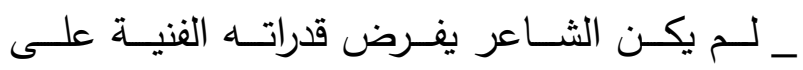
الأحاسيس والمشاعر والأشياء، بل كان يحاول نقلها

$$
\text { واقعيا في تصوير مُعبر موحي. }
$$

ــــــــام الصـور الجماليـة المتتوعـة وسـيلة منــه للنهوض بالمشاعر التي تختلج نفسه. ـ غياب المغالاة في الخيال، سواء حين يتحدث عن أحاسيسه، أم حين يُصَوّر ما أحاط به. ـــ إن اللغة تستطيع أن تربط بين رموزها وبين جميع

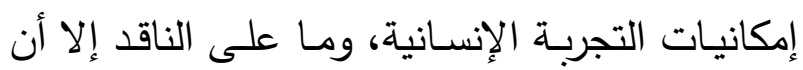
يتوســل تفاصــيلها لفــك شـفرات تجربــة الثـــاعر الإنسانية.

\section{المصادر والمراجع - - اجع}

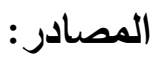

ابن الأثير، ضياء الدين ابن الأثير( 909 (م). المثل

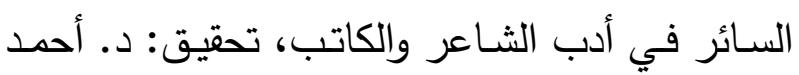
الحـوفي، د. بــدوي طبانــه، د.ط، القــاهرة، مكتبــة النهضة.

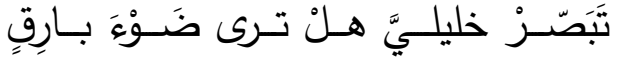

يضيءُ الأُجىى بالليلِ عنْ سَرْوِ حِيْرَا

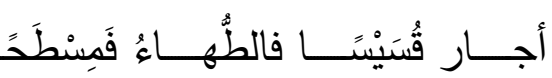

وجَوًَا فروَى نخْلَ قيَسِ بنِ شَمَّرا

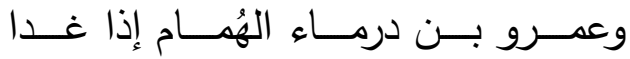

بذي شُطَبِ غضْبِ كَمَثْيَةِ قَسْوَرا

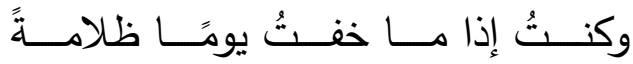

فإنَّ لها شعبًا ببلْطةِ زَتْمَرا

نِيافً

يظلُ الضبابُ فوقَهُ قد تَعصّرا"(or).

وهكذا يختم الشاعر قصيدته بهذه الحيْرة، ليكون بين قطبين يتـراوح بينهمـا: قطب الألم المُبـرح والخطر العظيم، وقطب الأمل المرجو.

لذلك نجده يحدّث صاحبيه اللذين يرافقانه ويشاركانه ألـم الغربـة، وهـو حديث للعمـوم على الخصـوص، ويطلب مـنهم أن ينظروا ويتأملوا إنْ كان ثــة أمسل للعودة واللقاء بالأهل والأحبة، والخلاص من دياجير ليطرو ظلمة الغربة والوحشة:

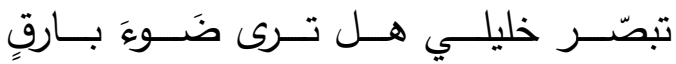
يضيء الاجى بالليل عن سر وحميرا وهذا يُمثّل حنينا قويـا منـه إلى الأوطان، ولهذا نجده يُسهب في ذكر الأماكن في أوطانه. مهـا لا شـك فـي أن القصـيدة تتميـز بهيمنــة ذات الشـاعر ، إذ لم تغادر شخصيته أجواء القصيدة كلها ولـو لحظـة واحـدة، تتحـرك وتتــامى مشـاعره ذات 


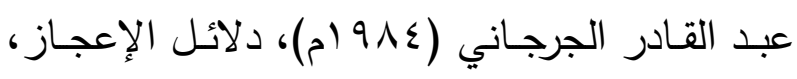
تحقيق: محمود شاكر ، د.ط، القاهرة، مطبعة المدني. الفرزدق ( 9NVV (م)، ديوان الفرزدق، شرح وضبط:

علي الفاعوري، طا، بيروت، دار الكتب العلمية.

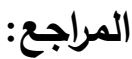
إيليا حـاوي ( • • (9م)، امـرؤ القيس، شـاعر المرأة والطبيعة، طا، بيروت، دار الثقافة للنشر .

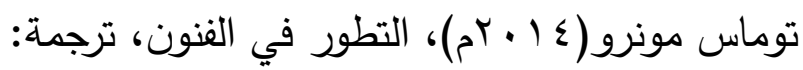

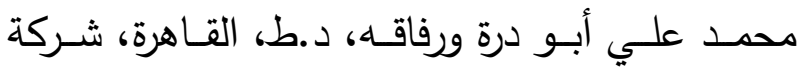
الأمل للطباعة والنشر . جان كوهن ( بـ19 (م)، بنية اللغة الشعرية، ترجمة: محمد الولي ومحمد العمري، دار توبقال. حسن البنـا، عـز الدين ( د.ت)، الكلمـات والأشـياء

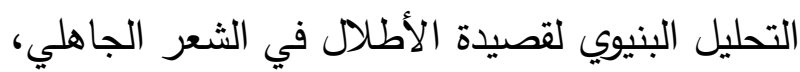

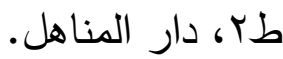
حسـين خريـوش ( 999 (م)، بنيـة التـراث الروحي الاجتماعي في مرثية طليطلة، المجلة العربية للعلوم

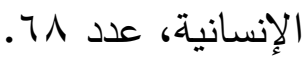
السـعيد الــورقي (11 ( • بم)، لغــة الثــعر العربـي الحديث، د.ط، الاسكندرية، دار المعرفة الجامعية.

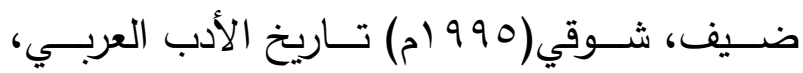
العصر الجاهلي، طهץ ، القاهرة، دار المعارف.

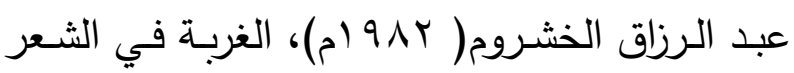

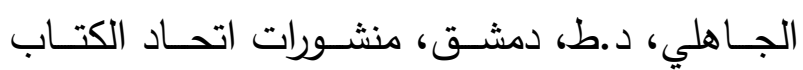

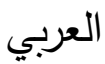

ابن أحمد، حسين بن أحمد الزوزني( ب99 (م)، شرح المعلقـات السـبع، تحقيق: لجنـة التحقيق في الـدار العالمية، د.ط، بيروت، الدار العالمية.

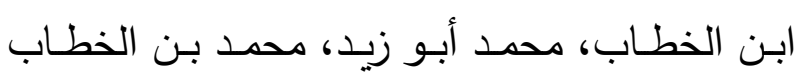

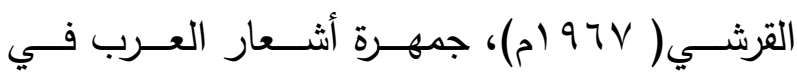

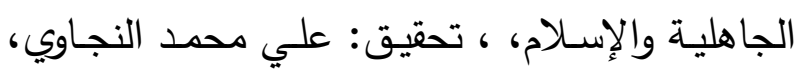
د.ط، القاهرة، دار نهضة مصر .

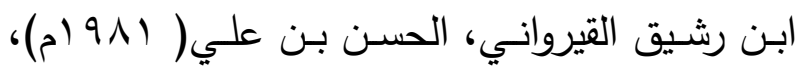

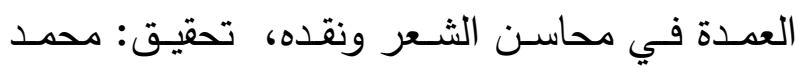
محيي الدين عبد الحميد، د.ط، بيروت، دار الجيل.

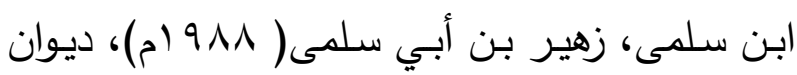

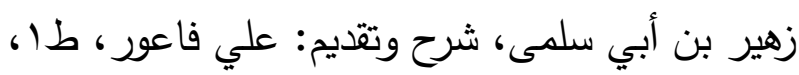
بيروت، دار الكتب العلمية.

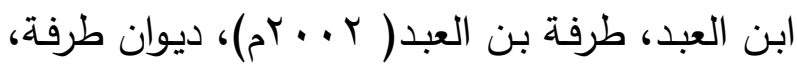
تحقيـق: محمـــ ناصـر الـدين، طس، بيـروت، دار

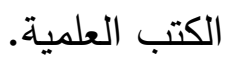

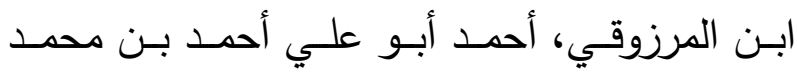
المرزوقي ( (991 (م)، شرح ديوان الحماسة، تحقيق:

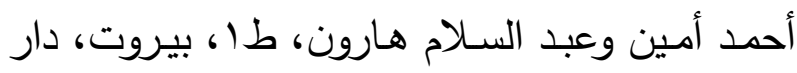

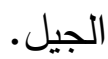
امرؤ القيس ( عـ9 (م)، ديوان امرئ القيس، تحقبق: أبو الفضل إبراهيم، طء، بيروت، دار المعارف.

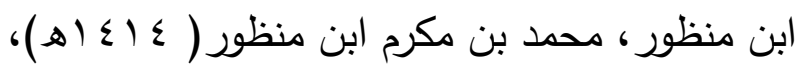
لسان العرب، طז، بيروت، دار صادر •

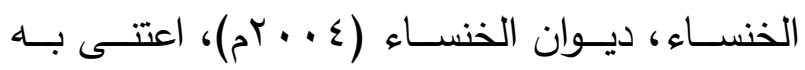
وشرحه، حمدو كمّاس، طץ، بيروت، دار المعرفة. 
qr

خطاب شجن الذات ما بين الآمال والآلام- قراءة نصية لنماذج من شعر امرئ القيّس

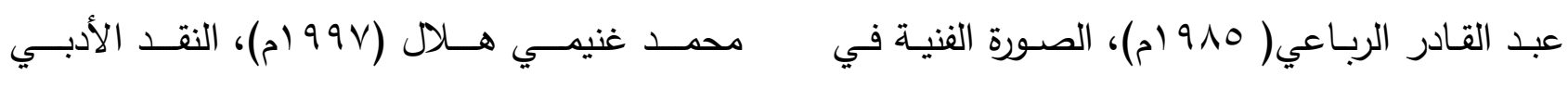
الحديث، د.ط، القاهرة، دار العودة.

النقد الشعري، طب، إربد، الأردن، مكتبة الكندي.

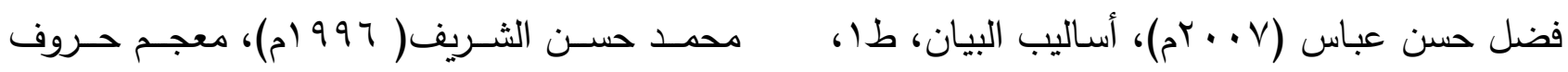

المعـاني في القـرآن الكـريم، طا ا، بيـروت، مؤسسـة

الأردن، دار النفائس.

الفرد ادلر ( ع99 (م)، علم النفس الفردي، ترجمـة الرسالة.

وهيب طنوس ( جلو (م)، الوطن في الشعر العربي

وتحقيق: أحمد فائق، د.ط، بيروت، مكتبة الأسرة.

كمـال أبـو ديـب ( ج191 (م)، الـرؤى المقنعـة، د.ط، من الجاهلية إلى نهاية القرن الثاني عشر الميلادي،

طا ، دمشق، جامعة حلب.

القاهرة، الهيئة المصرية العامة للكتاب. 


\title{
Discourse of self-denunciation between hopes and pains - text reading of examples of the poetry of Amri Al Qays
}

\author{
Mahmoud Saleem Hayajneh \\ Professor of literature and co_critic
}

\begin{abstract}
. the study attempted to reveal the prison about a phenomenon that appeared to be obvious in the introductions of the man of al-Qais al-Taalit, and some of his poems. This phenomenon is a phenomenon of self-expression between hopes and pains. Therefore, the consistency data in the texts were monitored in light of its references. The reading found that the construction of the pretensions has been woven on rules that seemed tight in the whole to the anxiety and tension manifested clearly between the two times they encounter: past and present, and the two senses: hope and pain, which created a state of constant anxiety and psychological distress has led to the signs persist in the same Poet.

In this regard, the study stood at this phenomenon, trying to discover it, in order to stand on its contents and psychological references to the establishment of this phenomenon, which has become a special format in many of his introductions and some of his poems.

Keywords: Amor al-Qais, self-aggrandizement, hope and pain, speech
\end{abstract}

